\title{
IMPUTACIÓN DE CONDUCTAS PUNIBLES COMETIDAS POR GRUPOS DE CRIMEN ORGANIZADO
}

\author{
Daniel Medina García* \\ Miguel Sebastián Ortiz Rivero**
}

\begin{abstract}
Resumen: La delincuencia organizada es un fenómeno que afecta de manera ostensible la seguridad ciudadana y la institucionalidad de un Estado. Por lo anterior resulta útil explicar cómo se puede reprimir esta forma de criminalidad por parte del derecho penal, a pesar de que los delitos cometidos por estos grupos en ocasiones son atribuibles a sujetos que no intervienen en la ejecución de ellos.
\end{abstract}

Palabras clave: función de la pena; criminalidad organizada; dominio del hecho; intervención delictiva; infracción de deberes; derecho penal internacional.

* Abogado, especialista en Ciencias Penales y Criminológicas, especialista en Derecho Procesal Penal y magíster en Derecho de la Universidad Externado de Colombia. Bogotá (Colombia). Correo-e: drdanielmedina@gmail.com.

** Abogado de la Universidad Católica de Colombia, especialista en Derecho Penal y Ciencias Forenses de la misma universidad y magíster en Derecho de la Universidad Externado de Colombia. Bogotá (Colombia). Correo-e: sebastianortiz9@hotmail.com. Fecha de recepción: 30 de abril de 2020. Fecha de aceptación: 12 de enero de 2021. Para citar el artículo: Daniel Medina García, Miguel Sebastián Ortiz Rivero. "Imputación de conductas punibles cometidas por grupos de crimen organizado", Revista Derecho Penal y Criminología, vol. 41, n. ${ }^{\circ} 111$, julio-diciembre de 2020, Bogotá, Universidad Externado de Colombia,pp. 207-256. Dor: https://doi.org/10.18601/01210483. v41n111.07. 


\title{
ATTRIBUTION OF PUNISHABLE BEHAVIORS COMMITTED BY GROUPS OF ORGANIZED CRIME
}

\begin{abstract}
Organized crime is a phenomenon that affects ostensibly citizen security and the institutionality of a State. Therefore, is useful to explain how this form of criminality can be repressed by criminal law, in spite of the crimes commited by these organizations are attributable to members that do not intervene in the execution of them.
\end{abstract}

Keywords: function of the penalty; organized crime; mastery of the fact; criminal intervention; breach of duties; international criminal law.

\section{INTRODUCCIÓN}

La criminalidad organizada es un fenómeno delincuencial de gran impacto social que implica un peligro para la institucionalidad de un Estado, el orden social justo y el ejercicio de los derechos y libertades de los ciudadanos, por tanto, debe ser combatido con toda contundencia por las autoridades.

Una de las herramientas con las que cuenta el Estado para reprimir el delito es la imposición de una pena estatal, por ello se deben reprimir los crímenes ocurridos en el seno de un grupo de crimen organizado por medio de la imposición de una pena estatal; sin embargo, esta herramienta no se puede utilizar de manera indiscriminada y arbitraria, sino que se debe imponer en el marco del derecho penal y acatando las garantías, las finalidades y los métodos de atribución de conductas previstas en esta disciplina jurídica.

Los delitos cometidos por grupos de crimen organizado no son de fácil represión penal, pues en las estructuras de delincuencia organizada se cometen conductas como tráfico de estupefacientes, trata de personas, secuestros o hurtos, entre otros, y solo se puede reprimir con una pena estatal a quienes les corresponda responsabilidad penal individual por la comisión de estos delitos, no a todos los integrantes de un grupo de crimen organizado por el hecho de pertenecer a este tipo de organizaciones.

Partiendo de esto, es claro que la represión penal de los delitos cometidos en una agrupación de criminalidad organizada tiene cierto grado de complejidad, ya que en ocasiones los responsables de la comisión de estos delitos son sujetos que no intervienen en la ejecución de las conductas, como en el caso de los cabecillas o los coordinadores de personal delincuente, por eso consideramos útil determinar si nuestra legislación penal cuenta con lo necesario para atribuir responsabilidad penal a quienes intervienen en conductas realizadas por grupos de criminalidad organizada, inclusive quienes no intervienen en la ejecución de los hechos punibles. 
En este trabajo pretendemos abordar la forma como el derecho penal puede reprimir los delitos cometidos por grupos de crimen organizado atribuyendo responsabilidad penal, lo que aboca a la imposición de una pena, sin tocar temas referentes a la forma como se debe ejecutar la pena, los delitos que se deban crear en la ley para reprimir el crimen organizado o los aspectos forenses y procesales que hacen más eficaz la lucha contra esta criminalidad.

\section{FUNCIONES DE LA PENA}

El derecho penal es un instrumento para racionalizar el uso del ius puniendi que tiene el Estado para reprimir ciertas conductas ${ }^{1}$, por ende, se interesa por garantizar que esta tarea represiva no carezca de contenido legitimador o justificación y que no se convierta en una manera de adoctrinar a la sociedad y las personas o en un manual de conducta o de moralidad $^{2}$.

El Estado prohíbe ciertas conductas calificadas como delitos y prevé la imposición de una pena como una consecuencia por infringir estas prohibiciones y como una herramienta para combatir la criminalidad, incluyendo la criminalidad organizada.

La pena estatal solo se debería imponer a quien se le atribuya responsabilidad penal por la comisión de una conducta delictiva según criterios objetivos y estables, esto para no convertir la potestad de irrogar una pena en un proceder caprichoso y arbitrario ${ }^{3}$.

De igual forma, para que una pena estatal se considere justa, proporcional y adecuada es necesario saber qué busca, toda vez que si no se consultan los fines que busca la pena, esta se tornaría en un mal innecesario, irrazonable y desproporcionado.

Aunado a esto, para determinar qué debe reprimir el Estado por medio de la pena es necesario conocer cuál es la finalidad de esta, pues sabiendo para qué sirve la pena se puede determinar qué debe perseguir penalmente el Estado: verbigracia, si con la aplicación de una pena se busca intimidar a los ciudadanos para que no se cometan delitos, lo esperable es que la pena se imponga para prevenir la comisión de comportamientos voluntarios; si la pena se impone para mantener la expectativa de que el orden normativo sigue vigente y no ha cambiado, lo esperable es que la pena se imponga por infracciones al orden vigente; si con la pena se busca intimidar, asegurar, controlar o inocuizar a los criminales, la pena se fijará atendiendo las calidades personales de estos.

1 José Urbano Martínez. "Concepto y función del derecho penal”, en Lecciones de derecho penal, parte general, Bogotá, Universidad Externado de Colombia, 2002, pp. 19 y 20.

2 Carlos Arturo Gómez Pavajeau. Introducción al derecho penal constitucional, Bogotá, Ediciones Nueva Jurídica, 2012, pp. 18 y ss.

3 Heiko Lesch. La función de la pena, Jaime Sánchez Vera Gómez Trelles (trad.), Bogotá, Universidad Externado de Colombia, 2000, p. 16. 


\subsection{Teorías de la pena}

Como ya es sabido y se puede observar en los manuales más elementales de derecho penal, hay teorías que tratan de explicar la función de la pena. Entre estas teorías están las llamadas "teorías absolutas" y las llamadas "teorías relativas" ; para efectos del desarrollo de este trabajo nos referiremos a ellas.

\subsubsection{Teorías absolutas de la pena}

Para hacer una breve referencia a estas teorías de la pena resulta imprescindible recordar las disertaciones de Kant sobre la imposición de la pena. Este filósofo indicaba que la pena es una reacción legítima del Estado para satisfacer la idea de justicia y restablecer el orden perturbado por el hecho ${ }^{5}$.

Hegel compartía esta idea, pero consideraba que la función de la pena también debía tener una proyección social ${ }^{6}$. Este pensador indicaba que hay una voluntad general, que es el derecho como idea u orden moral existente, y este orden moral puede correr el riesgo de ser negado con la comisión de un delito, que es una voluntad particular, pues la comisión de un delito da un mensaje que indica que no se cumple la voluntad general por el ejercicio de una voluntad particular, por ello es necesario negar el mensaje que intenta negar la voluntad general.

Hay formas de negar la idea de que no se cumple la voluntad general. Una de ellas es vengarse del delito que se cometió. Sin embargo, la venganza es una negación de la voluntad particular que intentó negar la voluntad general por medio de otra voluntad particular no institucionalizada y sin control de proporciones que no comunica que la voluntad general se sobrepone sobre una voluntad particular, sino que hay una voluntad particular que es más fuerte que otra voluntad particular.

La voluntad particular del delito también puede ser negada con la imposición de una pena estatal e institucionalizada. Con esta negación de la voluntad particular se impone el derecho como idea o como voluntad general7; además, la magnitud de esta negación del delito se gradúa de acuerdo con las necesidades de la sociedad y por un proceso institucional, pues si la sociedad no necesita negar de una manera tan enérgica el mensaje que transmite el delito, no será necesario imponer una pena tan grave, y si,

4 Carmen Eloísa Ruiz López y Miguel Córdoba Angulo. Lecciones de derecho penal, parte general, 3. ${ }^{a}$ ed., Bogotá, Universidad Externado de Colombia, 2019, pp. 30 a 32.

5 Immanuel Kant. La metafísica de las costumbres, traducción y notas de Adela Cortina y Jesús Conill, 4. ' ed., Madrid, Tecnos, 2004, pp. 331 y ss.

6 Georg Wilhelm Friedrich Hegel. Filosofía del derecho, traducción de Angélica Mendoza, 5. ed., Buenos Aires, 1968, pp. 187 y ss.

7 Ibídem. 
por el contrario, la sociedad necesita combatir el mensaje que genera el delito de una manera más vehemente se impondrá una pena más grave, de esta forma se halla una respuesta a la voluntad particular del delito equilibrada, proporcional y sin excesos ${ }^{8}$.

En síntesis, con las teorías absolutas de la pena se atribuye a la pena estatal la función de restablecer la idea de justicia y el orden moral establecido, pero de manera proporcional, sin excesos ni arbitrariedades y según lo merecido por la comisión de un delito.

\subsubsection{Teorías relativas}

Las teorías relativas de la pena son teorías que no se conforman con la implementación de la justicia como reacción proporcional al injusto cometido por un delincuente, pues buscan fines adicionales como prevenir delitos, proveer mayor seguridad a la sociedad o satisfacer fines sociales adicionales a la satisfacción de la justicia.

Entre las teorías relativas de la pena más conocidas encontramos las de la prevención especial y las de la prevención general; sin embargo, para este trabajo no resulta enfocado referirnos a la teoría de la prevención especial, pues esta teoría sirve para fundamentar la forma como las autoridades penitenciarias ejecutan la pena y la forma como los jueces gradúan la pena, distinto de lo que ocurre con las teorías de la prevención general negativa y prevención general positiva, que también sirven para fundamentar un modelo de imputación de conductas, como se verá a continuación.

\section{a) Prevención general negativa o por intimidación}

La teoría de la prevención general fue propalada en la doctrina penal por Feuerbach a comienzos del siglo XIX, esta teoría plantea que la imposición de una pena estatal debe causar una intimidación en los ciudadanos para que se abstengan de cometer delitos, esto bajo la amenaza de que se les imponga una pena en caso de llevar a cabo alguna conducta punible ${ }^{9}$.

Según esta teoría, para que la pena surta efectos debe consagrarse en la ley con el fin de que los ciudadanos sepan que en caso de cometer delitos se les impondrá una pena y se convenzan de no delinquir; sin embargo, para que esta pena tenga eficacia es necesario que no se quede como una simple previsión legal, por ello al presentarse la eventualidad de la comisión de delitos, la pena debe ser impuesta por la autoridad competente.

8 Ídem.

9 Anselm Ritter von Feuerbach. Lehrbuch des Peinlichen Rechts, 11. ${ }^{a}$ ed., 1832, parágrafos 12 y ss. Citado por Santiago Mir Puig. Introducción a las bases del derecho penal, 2. ${ }^{a}$ ed., Buenos Aires, B de F, 2003, p. 33 . 
No obstante lo anterior, para que la pena impuesta tenga credibilidad y disuada de cometer delitos debe ser lo suficientemente grave y su imposición lo suficientemente segura como para que el eventual autor de un delito encuentre menor satisfacción en cometer el delito que en evitar ser castigado y en virtud de este convencimiento prefiera no delinquir ${ }^{10}$.

Como se ha indicado, esta teoría concibe la pena como un medio de coacción, es decir, como una herramienta para influir en los comportamientos voluntarios; por lo anterior podemos decir que esta teoría se enmarca en modelos de imputación penal en los que importan de manera prevalente las manifestaciones voluntarias del comportamiento que degeneran en injustos penales.

Un referente mundial en la doctrina penal como el profesor Claus Roxin, que defiende la aplicación de esta teoría cuando el juez irroga una pena ${ }^{11}$, considera que en la imposición de una pena no solo es necesario determinar en qué grado se desea prevenir la comisión de un comportamiento voluntario, sino determinar cuál es la medida o la gravedad que debe tener la pena impuesta; para estos efectos apelaba a la noción de culpabilidad como límite a la imposición de la pena, entendida como la capacidad de actuar de una manera distinta a la prohibida por la ley penal conforme al grado de libertad y conciencia de la persona que cometió la infracción penal ${ }^{12}$.

Esto indica que para la teoría de la prevención general por intimidación la función de la pena está determinada por la posibilidad de incidir en los comportamientos voluntarios de los destinatarios de la ley.

\section{b) Prevención general positiva}

La teoría de la prevención general positiva parte del hecho de que la función que cumple la pena es la de mantener la vigencia de la norma. Sin embargo, esta es una función que requiere un replanteamiento del concepto tradicional de la norma penal que concibe las normas como prescripciones que pretenden dirigir las conductas de los destinatarios por medio de órdenes y prohibiciones (norma subjetiva de determinación); e indicar que los intereses son importantes para el ordenamiento penal

10 Feuerbach. Kritik des natürlichen Rechts als Propädeutik zu einer Wissenschaft der natürlichen Rechte. Citado por Günther Jakobs. "La pena estatal: significado y finalidad”, en Derecho penal y sociedad, Eduardo Montealegre (coord.), Bogotá, Universidad Externado de Colombia, 2007, pp. 17 y ss.

11 Claus Roxin. Problemas básicos del derecho penal, traducción de Diego Manuel Luzón Peña, Madrid, Reus, 1976, pp. 20 y ss. Este autor considera que la pena cumple una función de prevención general por intimidación cuando el legislador establece en la ley, una función de prevención general por intimidación y de prevención especial cuando el juez la impone y una función de prevención especial cuando se ejecuta la pena.

12 Ibíd. 26 y ss. 
(norma objetiva de valoración) ${ }^{13}$. En la teoría de la prevención general positiva se parte del hecho de que para el derecho penal no es importante si las normas son subjetivas de determinación u objetivas de valoración, sino si son expectativas de cómo se actúa en sociedad y de qué comportamientos se pueden esperar, en este sentido, las normas dan confianza sobre las conductas que se pueden esperar viviendo en sociedad ${ }^{14}$.

Para esta teoría, antes de que existiera sociedad había un cúmulo de humanos que no se coordinaban entre sí porque no entendían cómo podría actuar el otro, y sin conocer esto, no sabían cómo orientarse. Esta contingencia e incertidumbre se elimina con actos y acontecimientos que comunican un mensaje y con ello crean expectativas comunes de cómo se va a actuar o qué va a ocurrir ${ }^{15}$. La sociedad está compuesta por estos actos de comunicación y, así como las conductas de los ciudadanos generan expectativas de cómo se va a actuar, las normas penales también son expectativas de conducta que comunican cómo se espera que se comporten las personas.

Sobre esta base, al derecho penal solo le importan los comportamientos que comuniquen, y más específicamente los comportamientos que comuniquen que las expectativas contenidas en las normas no están vigentes. Es decir: al derecho penal, más que la voluntad de las personas, le importan las infracciones al derecho o las infracciones de deberes que comuniquen que las normas o expectativas de conducta no están vigentes y no son obligatorias ${ }^{16}$.

En este marco conceptual la pena cumple la función de confirmar la vigencia de las normas o de las expectativas normativas contenidas en la ley, pues, al existir un delito, esta conducta comunica que se puede delinquir o que la norma que prohíbe delinquir no está vigente o no obliga, por tanto el Estado debe comunicar que la conducta del delincuente de infringir la norma está desaprobada para confirmar que la norma sigue vigente y sigue siendo obligatoria ${ }^{17}$, y esto se comunica por medio de la imposición de una sanción penal.

Este cambio de paradigma en la función de la pena tiene repercusiones en la teoría del delito y en la forma de imputar responsabilidad penal, pues ya no van a importar

13 Carlos Arturo Gómez Pavajeau. Estudios de dogmática en el nuevo código penal, parte I, 3. a ed., Bogotá, Giro Editores, 2009, pp. 231 y ss.; Tatjana Hörnle. Teorías de la pena, traducción de Nuria Pastor, Bogotá, Universidad Externado de Colombia, 2015, pp. 18 y 19.

14 María Eloísa Quintero. “Acción, comunicación e injusto penal”, en Derecho penal y sociedad, Eduardo Montealegre (coord.), Bogotá, Universidad Externado de Colombia, 2007, p. 150.

15 Juan Antonio García Amado. La filosofía del derecho de Habermas y Luhmann, Bogotá, Universidad Externado de Colombia, 1997, pp. 104 y ss.

16 Günther Jakobs. Estudios de derecho penal, traducción de Enrique Peñaranda, Carlos Suárez y Manuel Cancio, Madrid, Civitas y Universidad Autónoma de Madrid, 1997, pp. 73 y ss.

17 Günther Jakobs. Sobre la teoría de la pena, traducción de Manuel Cancio Meliá, Bogotá, Universidad Externado de Colombia, 1998, p. 16. 
tanto para imputar responsabilidad penal los comportamientos voluntarios que degeneran en delito, sino las infracciones de deberes jurídicos que comunican un mensaje con sentido delictivo.

\subsection{Teoría de la pena adecuada a nuestro ordenamiento}

La pena estatal es una manifestación de la política criminal del Estado ${ }^{18}$ que obedece a los contenidos axiológicos que inspiran a este ${ }^{19}$ y que se pueden observar en la parte dogmática de la Constitución. De estos contenidos axiológicos se desprenden condicionamientos para el funcionamiento del Estado y, como consecuencia de esto, para la imposición de la pena estatal; por esto, resulta útil referirnos a estos contenidos antes de hablar de la función de la pena, pues de nada sirve disertar sobre la función de una pena sin saber si esta es procedente, por no observar los requerimientos normativos que impone el modelo de Estado para la imposición de aquella.

Desde el artículo 1. ${ }^{\circ}$ de la Constitución es palmario que nuestro Estado está constituido como un "Estado social de derecho" fundado "en el respeto de la dignidad humana", de lo que se desprende que, como todo Estado de derecho moderno, somete su funcionamiento al principio de legalidad y al respeto de los derechos fundamentales ${ }^{20}$.

Partiendo de esto, resulta obligatorio reconocer que el principio de legalidad se instituye como un condicionamiento imprescindible para el funcionamiento del Estado. Por ello las funciones de declarar responsabilidad penal e imponer una pena, como manifestaciones del Estado, se deben ejercer de conformidad con la ley, por las conductas previstas en la ley, con las precisiones indicadas en la ley y con las exigencias previstas en ley. Esto quiere decir que "La ley penal definirá de manera inequívoca, expresa y clara las características básicas estructurales del tipo penal"21.

Con este principio también se materializa el principio de igualdad previsto en el artículo 13 de la Constitución y en el artículo 7. ${ }^{\circ}$ del Código Penal (en adelante, CP), con el cual se busca que la ley se aplique a todas las personas sin distinción y que, como consecuencia de esto, al resultar necesaria la imposición de una pena, esta se imponga sin discriminación ni arbitrariedad ${ }^{22}$ y dependiendo únicamente de factores objetivos para todos los individuos.

18 Corte Constitucional, sentencia C-939 de 2002.

19 Corte Constitucional, sentencia SU-747 de 1998.

20 Luis Villar Borda. "El Estado de derecho y el Estado social de derecho", en Revista Derecho del Estado, n. . 20, Bogotá, Universidad Externado de Colombia, 2007, p. 76.

21 Código Penal, artículo 10.

22 Carlos Arturo Gómez Pavajeau. Estudios de dogmática en el nuevo código penal, parte II, 3. a ed., Bogotá, Giro Editores, 2009, pp. 57 y ss. 
Además de esto, el hecho de que nuestra Constitución determine que nuestro Estado de derecho es social implica que su funcionamiento propenda al bienestar general de la sociedad ${ }^{23}$, por ello es entendible que la pena estatal deba obedecer a fines con proyección social, adicionales a la aplicación justa de la ley, como las funciones preventivas que procuran la realización del interés general.

En lo que atañe al respeto de la dignidad humana, nuestra Corte Constitucional ha reconocido a esta como valor supremo del Estado y la define como el "merecimiento de un trato especial que tiene toda persona por el hecho de ser tal" con la facultad "de exigir de los demás un trato acorde con su condición humana" 24 . Esto supone que el ser humano sea considerado libre, autónomo, capaz de orientarse y "un fin en sí mismo" y no pueda ser instrumentalizado para suplir los cometidos que tenga un Estado ${ }^{25}$.

Advirtiendo que el respeto a la dignidad humana se considera la más importante prioridad del Estado y el fin hacía donde debe tender su funcionamiento ${ }^{26}$, es un paso lógico reconocer el valor que merece en nuestro Estado el principio de responsabilidad subjetiva e individual, pues este es un desarrollo del principio de dignidad humana.

El principio de responsabilidad individual y subjetiva indica que el ser humano solo puede ser declarado penalmente responsable por razones que le sean realmente atribuibles al ejercicio de su libertad y no por conductas que le sean completamente ajenas o que le resultaren inevitables ${ }^{27}$, pues responsabilizar a una persona e imponerle una pena por esta clase de conductas sería tanto como utilizarla y sacrificarla para lograr resultados en un sistema de responsabilidad penal y cumplir las funciones sociales de la pena, lo cual, como indicamos, es contrario al respeto de la dignidad humana, pues el ser humano no es un instrumento para hacer funcionar al Estado, sino un fin en sí mismo.

Junto a los principios referidos encontramos el artículo $4 .^{\circ}$ del $\mathrm{CP}$, que adopta las funciones de retribución justa propia de las teorías absolutas de la pena y las teorías de la prevención general en este sentido:

Funciones de la pena. La pena cumplirá las funciones de prevención general, retribución justa, prevención especial, reinserción social y protección al condenado.

23 Carlos Arturo Gómez Pavajeau. Aspectos liberales y sociales del derecho penal, Bogotá, Ediciones Nueva Jurídica, 2013, p. 31.

24 Corte Constitucional, sentencia T-701 de 2006.

25 Corte Constitucional, sentencia T-499 de 1992.

26 Artículos $1 .^{\circ}, 2 .^{\circ}$ y $5 .^{\circ}$ de la Constitución.

27 Carlos Arturo Gómez Pavajeau. Introducción al derecho penal constitucional, cit., pp. 223 y ss. 
La prevención especial y la reinserción social operan en el momento de la ejecución de la pena de prisión.

Sobre la función de la pena de la prevención general que se encuentra en el anterior artículo del CP nuestra jurisprudencia ha entendido que se refiere tanto a la prevención general por intimidación como a la prevención general positiva, la Corte Constitucional las ha adoptado en nuestro ordenamiento en los siguientes términos:

La teoría de la prevención general negativa parte de la idea de que la pena tiene una finalidad intimidatoria, pues busca coaccionar psicológicamente a los potenciales delincuentes, de tal manera que mediante la amenaza y la ejecución posterior de la pena se logre hacer desistir la comisión de hechos punibles.

De otra parte, la teoría de la prevención general positiva, reitera su fundamento a partir del fin socialmente útil de la pena. Según Jakobs, la pena positivamente considerada es "[...] una muestra de la vigencia de la norma a costa de un responsable. De ahí surge un mal, pero la pena no ha cumplido ya su cometido con tal efecto, sino solo con la estabilización de la norma lesionada".

La base de esta teoría es el respeto al orden social, que se configura como un modelo de orientación para las interacciones sociales, por lo que los hombres puedan esperar siempre, en sus relaciones con los demás, que las normas vigentes serán respetadas por sus semejantes ${ }^{28}$.

Por su parte, la Corte Suprema de Justicia también ha adoptado las funciones de prevención general por intimidación y prevención general positiva como funciones de la pena de esta manera:

[...] la pena representa una amenaza dirigida a los ciudadanos para que se abstengan de incurrir en delitos [...]. Por ende, tanto la amenaza punitiva como la ejecución de la pena deben producir un efecto intimidatorio en los autores potenciales para así evitar que lleguen a delinquir.

Y a renglón seguido agrega:

la prevención general no puede fundarse exclusivamente en su efecto intimidatorio derivado (prevención general negativa), sino que, apuntando a fortalecer el consenso social, la pena también debe dirigirse a reforzar en la conciencia colectiva la vigencia del ordenamiento jurídico (prevención general positiva). Así, la pena tendría la tarea de demostrar frente a la comunidad la inquebrantabilidad del ordenamiento ${ }^{29}$.

28 Sentencia C-328 de 2016.

29 Corte Suprema de Justicia, radicación n. 33254 del 27 de febrero de 2013. 
Como hemos visto, las funciones que la pena estatal despliega en nuestro ordenamiento son de retribución, prevención general por intimidación y prevención general positiva (también las de resocialización, prevención especial, etc., solo que no se abordarán en este trabajo) y el ordenamiento intenta hacerlas compatibles, situación que será provechosa para explicar el tipo de imputación que se aplica para combatir el crimen organizado por medio del derecho penal. Sin embargo, resta decir para concluir este acápite que, como lo indica el artículo 3 del CP,

La imposición de la pena o de la medida de seguridad responderá a los principios de necesidad, proporcionalidad y razonabilidad.

El principio de necesidad se entenderá en el marco de la prevención y conforme a las instituciones que la desarrollan.

Esto quiere decir que, en virtud del principio de necesidad de la pena, la imposición de esta debe ser útil y servir para cumplir las funciones que el legislador le ha asignado a la pena ${ }^{30}$, pero siendo justa y proporcional de acuerdo con la gravedad del hecho, el grado de intervención en él y la culpabilidad del autor ${ }^{31}$, lo que se equilibra con la función de retribución justa de las teorías absolutas de la pena en consonancia con las teorías relativas de la pena.

\section{ASPECTOS GENERALES DE LA CRIMINALIDAD ORGANIZADA}

Hemos hecho alusión a unas funciones de la pena adoptadas por nuestro ordenamiento que consideramos útiles para determinar una forma de imputar responsabilidad penal a quienes intervienen en la comisión de delito. Sin embargo, debemos recordar que el objetivo de este estudio es encontrar un modelo de imputación de conductas punibles aplicable a los delitos cometidos en un grupo de crimen organizado, por ello resulta indispensable explicar unas generalidades de este tipo de criminalidad.

Antes de intentar determinar el concepto de criminalidad organizada para abordar el objeto de este trabajo, debemos advertir que hay opiniones que censuran la determinación conceptual de esta clase de criminalidad debido a que no tiene una estricta tipificación y determinación en la ley y no define cuáles son las actividades que se pretenden perseguir penalmente con la consagración de esta clasificación; de hecho, estos opinadores consideran que esta categoría es útil para legitimar la expansión injustificada del derecho penal, la atribución de responsabilidad penal de manera

30 Corte Constitucional, sentencia C-806 de 2002.

31 Iván González Amado. "La punibilidad", en Lecciones de derecho penal, parte general, Bogotá, Universidad Externado de Colombia, 2002, p. 416. 
arbitraria a quienes pertenecen a grupos que se consideran de crimen organizado y la restricción de libertades sin provecho alguno para la sociedad ${ }^{32}$.

Aunado a esto, otro sector considera que la delincuencia organizada puede llegar a tener alcance transnacional y tiene particularidades dependiendo las regiones donde se presenta y las condiciones sociales de dichas regiones, pues no es igual la criminalidad de la mafia rusa, de la yakuza japonesa, de las maras de Centroamérica, de las bandas criminales colombianas y de los carteles mexicanos, entre otros, y esto dificulta la conceptualización de una categoría de criminalidad que abarque todas estas formas de delincuencia y sus matices ${ }^{33}$.

A pesar de lo anterior, consideramos que lo que se suele llamar "crimen organizado" es un fenómeno de macrocriminalidad de extrema gravedad, que perjudica bastante a la sociedad y debe ser enfrentado con determinación por parte de nuestro Estado, por esto, la academia no puede cejar en su esfuerzo de explicar las distintas categorías de criminalidad, incluyendo la delincuencia organizada, pues el entendimiento de este tipo de criminalidad posibilita encontrar formas de combatir este fenómeno que no se encontrarían si se considera esta forma de delincuencia una eventualidad aislada, individual y descontextualizada, ya que es equivocado enfrentar un fenómeno que no se conoce y del que no se saben sus rasgos característicos.

\subsection{Generalidades conceptuales del crimen organizado}

El crimen organizado, como asunto de trascendencia global, ha sido objeto de atención por la comunidad internacional que en instrumentos como la Declaración Política y Plan de Acción Mundial de Nápoles contra la Delincuencia Transnacional Organizada de 1994 de la Asamblea General de la ONU, que dijo:

La comunidad internacional deberá definir de común acuerdo un concepto de delincuencia organizada que sirva de base para la adopción de respuestas nacionales más compatibles entre sí, y para una cooperación internacional más eficaz.

Para combatir eficazmente la delincuencia organizada, los Estados deberán tener en cuenta las características estructurales y el modus operandi de este tipo de delincuencia al formular estrategias, políticas y medidas legislativas y de otra índole. Sin que constituyan una definición cabal y jurídica del fenómeno, cabe considerar como típicas las siguientes características: la formación de grupos

32 Eugenio Zaffaroni. El crimen organizado: una categoría frustrada, Bogotá, Leyer, 1996, pp. 16 y 40.

33 Laura Zúñiga. "Criminalidad organizada, derecho penal y sociedad. Apuntes para el análisis", en Revista Foro Jurídico, n. ${ }^{\circ}$ 10, Lima, Pontificia Universidad de Perú, 2010, pp. 158 y ss. 
para dedicarse a la delincuencia; los vínculos jerárquicos o las relaciones personales que permiten el control del grupo por sus jefes; el recurso a la violencia, la intimidación o la corrupción para obtener beneficios o ejercer el control de algún territorio o mercado; el blanqueo de fondos de procedencia ilícita para los fines de alguna actividad delictiva o para infiltrar alguna actividad económica legítima; el potencial para introducirse en alguna nueva actividad o para extenderse más allá de las fronteras nacionales; y la cooperación con otros grupos organizados de delincuentes transnacionales.

Este instrumento no convencional fue el insumo y la motivación para la famosa Convención de Palermo, que definía el crimen organizado de esta manera ${ }^{34}$.

Por "grupo delictivo organizado" se entenderá un grupo estructurado de tres o más personas que exista durante cierto tiempo y que actúe concertadamente con el propósito de cometer uno o más delitos graves o delitos tipificados con arreglo a la presente Convención con miras a obtener, directa o indirectamente, un beneficio económico u otro beneficio de orden material.

Por grupo estructurado la Convención se refiere a

un grupo no formado fortuitamente para la comisión inmediata de un delito y en el que no necesariamente se haya asignado a sus miembros funciones formalmente definidas ni haya continuidad en la condición de miembro o exista una estructura desarrollada.

Por delitos graves la Convención se refiere a

la conducta que constituya un delito punible con una privación de libertad máxima de al menos cuatro años o con una pena más grave.

Por delitos tipificados con arreglo a la Convención se refiere al

acuerdo con una o más personas de cometer un delito grave con un propósito que guarde relación directa o indirecta con la obtención de un beneficio económico u otro beneficio de orden material [...].

La conducta de toda persona que, a sabiendas de la finalidad y actividad delictiva general de un grupo delictivo organizado o de su intención de cometer los delitos en cuestión, participe activamente en: a. Actividades ilícitas del grupo delictivo organizado; b. Otras actividades del grupo delictivo organizado, a

34 Convención de Naciones Unidas contra la delincuencia organizada transnacional, artículo 2. 
sabiendas de que su participación contribuirá al logro de la finalidad delictiva antes descrita; [...]

La organización, dirección, ayuda, incitación, facilitación o asesoramiento en aras de la comisión de un delito grave que entrañe la participación de un grupo delictivo organizado [...]

Delitos graves que entrañen la participación de grupos delictivos organizados [...]

La conversión o la transferencia de bienes, a sabiendas de que esos bienes son producto del delito, con el propósito de ocultar o disimular el origen ilícito de los bienes o ayudar a cualquier persona involucrada en la comisión del delito determinante a eludir las consecuencias jurídicas de sus actos; [...]

La ocultación o disimulación de la verdadera naturaleza, origen, ubicación, disposición, movimiento o propiedad de bienes o del legítimo derecho a éstos, a sabiendas de que dichos bienes son producto del delito; [...]

La adquisición, posesión o utilización de bienes, a sabiendas, en el momento de su recepción, de que son producto del delito [...]

La promesa, el ofrecimiento o la concesión a un funcionario público, directa o indirectamente, de un beneficio indebido que redunde en su propio provecho o en el de otra persona o entidad, con el fin de que dicho funcionario actúe o se abstenga de actuar en el cumplimiento de sus funciones oficiales

La solicitud o aceptación por un funcionario público, directa o indirectamente, de un beneficio indebido que redunde en su propio provecho o en el de otra persona o entidad, con el fin de que dicho funcionario actúe o se abstenga de actuar en el cumplimiento de sus funciones oficiales [...]

El uso de fuerza física, amenazas o intimidación, o la promesa, el ofrecimiento o la concesión de un beneficio indebido para inducir a falso testimonio u obstaculizar la prestación de testimonio o la aportación de pruebas en un proceso en relación con la comisión de uno de los delitos comprendidos en la presente Convención;

El uso de fuerza física, amenazas o intimidación para obstaculizar el cumplimiento de las funciones oficiales de un funcionario de la justicia o de los servicios encargados de hacer cumplir la ley en relación con la comisión de los delitos comprendidos en la presente Convención. 


\subsubsection{Clasificación de grupos de crimen organizado en la legislación colombiana}

Además de estos instrumentos, nuestro Estado, mediante la Ley 1908 de 2018, adoptó la siguiente definición de grupos de delincuencia organizada ${ }^{35}$ :

Grupo delictivo organizado (GDO): El grupo estructurado de tres o más personas que exista durante cierto tiempo y que actúe concertadamente con el propósito de cometer uno o más delitos graves o delitos tipificados con arreglo a la Convención de Palermo, con miras a obtener, directa o indirectamente, un beneficio económico u otro beneficio de orden material.

Los delitos cometidos por estos grupos no necesariamente tendrán que ser de carácter transnacional sino que abarcarán también aquellos delitos que se encuentren tipificados en el Código Penal colombiano.

La Ley 1908 de 2018, al definir la categoría de grupos de delincuencia organizada (en adelante, GDO) resalta una especie o de estos GDO, los grupos armados organizados (en adelante, GAO). Los GAO son grupos de delincuencia o crimen organizado que operan en el marco de un conflicto armado y que tienen la particularidad de aplicar necesariamente reglas del $\mathrm{DIH}^{36}$, estos grupos se denominan de la siguiente manera ${ }^{37}$ :

"Grupos armados organizados" (GAO): Aquellos que, bajo la dirección de un mando responsable, ejerzan sobre una parte del territorio un control tal que les permita realizar operaciones militares sostenidas y concertadas.

Para identificar si se está frente a un grupo armado organizado se tendrán en cuenta los siguientes elementos concurrentes:

- Que use la violencia armada contra la Fuerza Pública u otras instituciones del Estado; la población civil; bienes civiles, o contra otros grupos armados.

- Que tenga la capacidad de generar un nivel de violencia armada que supere el de los disturbios y tensiones internas.

- Que tenga una organización y un mando que ejerza liderazgo o dirección sobre sus miembros, que le permitan usar la violencia contra la población civil, bienes civiles o la Fuerza Pública, en áreas del territorio nacional.

35 Ley 1908 de 2018, artículo 2.

36 Ángela Buitrago. "Delitos de grupos delictivos organizados y grupos armados organizados", en Lecciones de derecho penal, parte especial, vol. II, Universidad Externado de Colombia, 2019, pp. 420 y ss.

37 Ley 1908 de 2018, artículo 2. 
Aunque los GAO y los GDO se componen por varios miembros de una organización criminal destinada a cometer delitos, tienen diferencias, como las siguientes:

- Los GDO son una categoría de grupos de criminalidad colectiva y los GAO son una especie incluida en la categoría de GDO.

- Los GAO son grupos que generan un nivel de violencia que supera los simples disturbios o tensiones internas, mientras que pueden existir GDO que no siempre generan esta magnitud de violencia.

- Los GAO tienen recursos militares suficientes para enfrentar a la fuerza pública del Estado o a otros GAO y generar situaciones de hecho calificadas como conflicto armado.

- Según el artículo 2 de la Ley 1908 de 2018 los GAO requieren “la calificación previa del Consejo de Seguridad Nacional" para ser considerados GAO. Pese a lo anterior, la Corte Constitucional en la sentencia C-069 de 2020 sostuvo que "la definición de grupo armado organizado al margen de la ley ya está contemplada en el derecho internacional humanitario, en particular en el artículo 1.1 del Protocolo Adicional II a los Convenios de Ginebra de 1949".

- Según la Ley 1941 de 2018 en su artículo 3, se entienden por GAO el grupo "que, bajo la dirección de un mando responsable, ejerza sobre una parte del territorio un control tal que le permita realizar operaciones militares sostenidas y concertadas".

- En la represión y el enfrentamiento del Estado con los GAO o entre un GAO y otro se aplica el DIH, mientras que en la confrontación con GDO puede aplicarse regulación propia de estado de paz.

- El enfrentamiento en contra de los GDO que no son GAO debería realizarse por las fuerzas de policía del Estado, que es la autoridad instituida para el "mantenimiento de las condiciones necesarias para el ejercicio de los derechos y libertades públicas, y para asegurar que los habitantes de Colombia convivan en paz"38, mientras que el enfrentamiento en contra de los GAO requiere la intervención de las fuerzas militares que protegen eminentemente "la defensa de la soberanía, la independencia, la integridad del territorio nacional y del orden constitucional" 39 .

- De conformidad con la Ley 1941 que reformó la Ley 418 de 1997, los GAO son grupos susceptibles de ser beneficiados con procesos de paz para buscar su 
sometimiento a la justicia, aunque obviamente lo ideal es que deban ser confrontados y desarticulados por las fuerzas legítimas del Estado. Esto no ocurre con los GDO que no son GAO, a quienes el Estado debe desarticular antes de que se salgan de proporciones.

Los GAO requerían ser calificados de esta manera por el Consejo de Seguridad Nacional "para que el Gobierno nacional pueda examinar la posibilidad de decidir si adelanta diálogos conducentes a acuerdos para la desmovilización, desarme y reintegración del grupo" 40 . Esta necesidad fue suprimida por la sentencia C-069 de 2020 de la Corte Constitucional, aunque paradójicamente está vigente la exigencia de la certificación del Consejo Nacional de Seguridad que refiere el artículo 2. ${ }^{\circ}$ de la Ley 1908 de 2018 para considerar a un GAO como tal.

Independientemente de esta distinción es menester reiterar que tanto los GAO como los GDO son grupos de criminalidad organizada, y las diferencias de estos grupos de criminalidad colectiva deben partir de reconocer que los GAO son una especie del género conocido como GDO, solo que con las particularidades indicadas con anterioridad.

\subsubsection{Aspectos característicos de los grupos de crimen organizado}

Las normas citadas anteriormente fijan linderos para definir qué es un grupo de delincuencia organizada, sin embargo, permiten incluir en el género de grupos crimen organizado distintas categorías de criminalidad colectiva ${ }^{41}$, pues describen un concepto extremadamente amplio en el que encaja casi cualquier clase de criminalidad con pluralidad de personas, como la criminalidad común, el terrorismo, la corrupción o la criminalidad económica y empresarial; por ello, partiendo de la definición legal de "crimen organizado" es necesario limitar este concepto con los siguientes rasgos extralegales que definen la delincuencia organizada:

Es organizada. Los grupos de crimen organizado están compuestos por una pluralidad de personas, pero mucho más de tres, y se reconocen por tener una estructura jerárquica piramidal $^{42}$ o en racimos con jerarquía interna ${ }^{43}$ con distribución de rangos, roles y funciones dentro del grupo; un sistema de disciplina en el interior de la estructura ${ }^{44}$; la

40 Ley 418 de 1997, artículo 8, antes de la declaratoria de inexequibilidad de la sentencia C-069 de 2020 de la Corte Constitucional.

41 Samuel Malamud. "El concepto de crimen organizado: ciertos elementos para una mayor concreción", en Revista Chilena de Derecho y Ciencias Políticas, vol. 7, n. ${ }^{\circ}$ 1, Santiago, 2016, p. 78.

42 Laura Zúniga. Ob. cit., p. 165.

43 Julián López Muñoz. Criminalidad organizada. Aspectos jurídicos y criminológicos, Madrid, Editorial Dykinson, 2015, pp. 98 y ss.

44 Julián López Muñoz. Criminalidad organizada y terrorismo, Madrid, Editorial Dykinson, 2019, pp. 101 y ss. 
exigencia a los integrantes del grupo de no pertenecer a otros grupos de delincuencia organizada simultáneamente ${ }^{45}$ y una vocación de estabilidad y permanencia en el tiempo. Esto les permite coordinar la comisión de delitos graves y le da solidez e institucionalidad al grupo, inclusive cuando sobrepasa las fronteras territoriales de un Estado.

Estos grupos normalmente tienen tres niveles jerárquicos en su organización ${ }^{46:}$ (1) los directivos, que son la cúpula de los jefes con mayor recorrido y experticia en el deleznable oficio criminal, estos jefes dirigen la organización y las formas de alcanzar los fines del grupo delincuencial; (2) los miembros de base, que son los sujetos más vulnerables y reemplazables de la organización y cumplen las labores de ejecutar de propia mano los delitos planeados; y entre los anteriores rangos está (3) el nivel más heterogéneo, integrado por los sujetos que reciben indicaciones de los jefes y tienen cierta autonomía para coordinar y gestionar las tareas y dar indicaciones y órdenes a los integrantes de base del grupo.

Los grupos de delincuencia organizada se diferencian de otras colectividades, como las redes criminales, que no tienen una organización institucionalizada y pueden variar o modificarse con la ausencia de ciertos integrantes; las estructuras fluidas de criminalidad que están compuestas por sujetos que pueden hacer parte, salirse y reincorporarse en la agrupación con facilidad dependiendo determinadas circunstancias; o los grupos criminales, que es la denominación subsidiaria de grupos que no encajan en determinada clase de agrupación criminal ${ }^{47}$.

Gravedad de la actividad. Los grupos de crimen organizado se caracterizan por causar un grave daño social, por el uso generalizado de la violencia, cosa que los diferencia de la criminalidad empresarial o económica, y por la variedad de delitos cometidos, que van desde el narcotráfico y el contrabando hasta graves violaciones de derecho humanos y DIH, pasando por delitos medioambientales, de corrupción estatal y política y los que ponen en peligro la seguridad del Estado.

Esta delincuencia se distingue por ejercer un poder y un control territorial ocupando espacios rurales o urbanos que debería ocupar el Estado y no lo hace ${ }^{48}$. Esto, además de significar un grave peligro para los intereses de sus ciudadanos, acarrea un grave peligro para el Estado toda vez que debilita su presencia, autoridad y poder y con ello el orden vigente previsto en la Constitución y la ley, a tal punto de desacreditar la idea de que el Estado es la autoridad y el dueño del monopolio del uso de la fuerza y la violencia institucionalizada.

45 Samuel Malamud. Ob. cit., p. 80.

46 Carlos Sánchez. "Sobre el concepto de crimen organizado. Significación de su contenido en la legislación penal salvadoreña”, en Revista Policía y Seguridad Pública, n. o 2, El Salvador, 2012, pp. 52 y ss.

47 pp. 70 y ss.

48 Julián López Muñoz. Criminalidad organizada y terrorismo, cit., p. 102. 
La criminalidad organizada se caracteriza por poner en jaque al Estado de derecho, debilitarlo y cuestionar su credibilidad. Esto ocurre porque ejerce una violencia desbordada y una reiteración en el delito que intimida a la población y le genera un estado de temor, inseguridad y zozobra que le impide ejercer sus derechos ${ }^{49}$; porque corrompe políticos, medios de comunicación o líderes sociales para incidir en la sociedad y asegurar su impunidad y continuidad delictiva; y porque perturba legítimos sectores de la economía blanqueando los beneficios económicos de su actuar delictivo en actividades comerciales aparentemente honestas y en contratación con el Estado, lo cual redunda en externalidades que alteran en cierta medida el equilibrio de sectores lícitos de la economía y el funcionamiento del Estado ${ }^{50}$.

Planificación de la actividad delictiva. Los grupos de delincuencia organizada obran en función de un plan criminal normalmente dirigido y formulado por las altas cúpulas de las organizaciones y coordinado por rangos que supervisan a los ejecutores de los hechos punibles, esto con independencia de que en ocasiones los encargados de ejecutar el plan criminal (los miembros de base de la organización) cometan delitos que no están previstos en dicho plan.

Identidad propia de la organización. Los grupos de delincuencia organizada están estructurados de manera coordinada y articulada, y en sus delitos generalmente se puede observar un patrón de criminalidad o conjunto de rasgos comunes, como la frecuencia, la ubicación geográfica y la naturaleza de la conducta; inclusive, del conocimiento de determinado patrón de criminalidad se puede inferir si un crimen es atribuible a una organización o fue un evento dentro de un plan común de la organización criminal ${ }^{51}$.

Esto, aunado a la estructura institucionalizada de estos grupos, propicia que los delitos perpetrados por integrantes de estas organizaciones se vean por la ciudadanía como un acto de un grupo y no de personas individualmente consideradas, lo cual lleva a darle al colectivo una identidad distinta de la de sus integrantes; es decir, el grupo de crimen organizado pasa de ser visto como un cúmulo de delincuentes a ser visto como un sujeto que actúa y es susceptible de imputación.

Es común escuchar en alocuciones de medios de comunicación que el Clan del Golfo inició un paro armado o que el antiguo cartel de Medellín cometió determinado atentado. Esto sucede porque son grupos que cuentan con una identidad distinta de la de

49 Nicolás Santiago Cordini. "El 'crimen organizado': un concepto extraño al derecho penal argentino", en Revista Direito GV, vol. 2, n. ${ }^{\circ} 1$, Sao Paulo, 2017, p. 344.

50 Francisco Gutiérrez Sanín. "Conexiones coactivas: paramilitares y alcaldes en Colombia”, en Revista Análisis Político, vol. 28, n. ${ }^{\circ}$ 85, Bogotá, Universidad Nacional de Colombia, 2015, pp. 136 y ss.

51 Augusto Castañeda. La represión penal del crimen organizado: estrategias metodológicas para judicializar graves violaciones a los derechos humanos, Bogotá, Nueva Jurídica, 2018, p. 137. 
sus integrantes y son reputados como un foco de inseguridad y un objetivo de persecución por parte del Estado.

Persecución del lucro. El objetivo de este tipo de criminalidad es la consecución de lucro $^{52}$, mientras que el medio para alcanzar ese fin es el actuar delictivo. Es común que algunos grupos de crimen organizado quieran buscar reconocimiento político, sin embargo, la imagen de grupo político es una simple fachada para obtener algún trato privilegiado por parte de las autoridades ${ }^{53}$.

Estas organizaciones suelen tejer relaciones con líderes mal llamados "políticos", pero por finalidades distintas a las políticas, como asegurar la impunidad de sus crímenes, utilizar relaciones con funcionarios corruptos para lavar dinero por medio de la contratación estatal, asegurar la continuidad de los negocios y las operaciones delincuenciales o tener influencia en la sociedad.

Normalmente el crimen organizado es confundido con otra clase de criminalidad plural, organizada jerárquicamente, con identidad de grupo y que comete delitos graves como el terrorismo. No obstante, estas formas de criminalidad son distintas: verbigracia, el terrorismo tiene fines políticos como cambiar el orden político y el crimen organizado busca simplemente debilitar el Estado para poder delinquir sin dificultades ${ }^{54}$; los grupos de terrorismo no tienen problema en operar a pérdidas o sin rentabilidad económica y el crimen organizado persigue eminentemente el lucro; el crimen organizado en ocasiones opera subrepticiamente y el terrorismo siempre busca protagonismo e impacto mediático ${ }^{55}$.

\subsection{Necesidad de la pena}

Los grupos de crimen organizado cuentan con miembros de base que ejecutan de propia mano las conductas punibles y que, por lo general, son personas muy pobres reclutadas en un entorno de vulnerabilidad social y con pocas opciones de vida ${ }^{56}$.

52 Laura Zúñiga. Ob. cit., p. 163.

53 Un ejemplo de esto es el caso del Clan del Golfo, que ha intentado disfrazar su naturaleza de grupo de crimen organizado con la imagen de grupo político para evitar la extradición de sus líderes y adelantar un proceso de paz que implique beneficios jurídicos por los delitos que ha cometido. De hecho, este grupo "se hace llamar Autodefensas Gaitanistas de Colombia (AGC), y con ese nombre ha intentado obtener el reconocimiento político que los lleve a una negociación para obtener beneficios judiciales”: El Tiempo, “'Clan del Golfo’ buscó a Farc y Eln para evitar extradición”, Bogotá, 22 de abril de 2019, disponible en [https://www.eltiempo.com/justicia/conflicto-y-narcotrafico/ maniobras-con-las-que-clan-del-golfo-han-buscado-evitar-extradicion-351912].

54 Miguel Ángel Barrios. Seguridad ciudadana, de lo municipal a lo continental, Buenos Aires, Editorial Biblos, 2013,pp. 31 y ss.

55 Ibíd., 2915 y ss.

56 Julián López Muñoz. Criminalidad organizada y terrorismo, cit., pp. 45 y ss. 
No hay duda de que estas personas cometen hechos atroces y sobre ellos debe caer todo el peso de la ley e irrogárseles una pena estatal. No obstante, delincuentes de este tipo no son los elementos más importantes de una agrupación de delincuencia organizada y la persecución penal de estos no tiene la más mínima posibilidad de desarticular las estructuras criminales a las que pertenecen, cosa que sí pasaría persiguiendo penalmente a otros miembros de este tipo de organizaciones.

Teniendo en cuenta que la imposición de la pena es un elemento de represión con el que cuenta el Estado, los sistemas de imputación que consideran la conducta punible como una acción individual y aislada no posibilitan la imposición de la pena a sujetos que no ejecutan de propia mano la conducta pero sí intervienen significativamente en la comisión de conductas de un grupo de delincuencia organizada, y en ocasiones estos sujetos que no actúan de propia mano son a quienes el derecho penal debería perseguir, como a los jefes de las organizaciones criminales, pues no son sujetos fácilmente reemplazables en una organización criminal y sin estos miembros no habría un diseño de un plan criminal ni órdenes criminales.

En este entendido resulta provechoso imponer penas no solo a los ejecutores de propia mano, sino a todos los integrantes del grupo criminal que intervengan en la comisión de los delitos, esto con el fin de desarticular estas organizaciones criminales, dejar claro que el Estado de derecho debe someter a todos los criminales y hacer cumplir los fines de la pena.

\section{MODELOS DE IMPUTACIÓN}

El Estado, mediante la imposición de una pena, puede reprimir los delitos cometidos por grupos de crimen organizado. Teniendo en cuenta que estos delitos generalmente obedecen a un plan criminal y cuentan con la participación de distintos integrantes del grupo, resulta conveniente considerar estos delitos conductas colectivas (con pluralidad de intervinientes) y no conductas individuales perpetradas de manera aislada $^{57}$, pero sin llegar al extremo de pasar por alto principios como la responsabilidad individual y la proporcionalidad de la pena, pues un Estado que se funda en el respeto de la dignidad humana no puede dejar de respetar las garantías individuales del ser humano ni imponer penas que ignoren el grado de responsabilidad penal al momento de enfrentar fenómenos criminales complejos.

En esta parte del trabajo explicaremos las formas más recurrentes de imputar responsabilidad penal por la comisión de delitos cometidos por una agrupación de crimen organizado, aclarando que estas metodologías de imputación se predican tanto para los GDO como para los GAO, ya que estos son una especie de aquellos.

57 Ernst Joachim Lampe. La dogmática jurídico-penal entre la ontología social y el funcionalismo, traducción de Carlos Gómez, Guillermo Orce y Miguel Polaino, Lima, Grijley, 2003, pp. 97 y ss. 
Las técnicas de imputación que se abordarán a continuación se aplican a delitos cometidos por agrupaciones con las siguientes características: (1) grupos organizados, es decir, con pluralidad de personas, con estructura jerárquica, con distribución de rangos, roles y funciones dentro del grupo, con un sistema de disciplina en el interior de la estructura y con una vocación de estabilidad y permanencia en el tiempo; (2) grupos con identidad, en otras palabras, grupos que son vistos por la ciudadanía como un ente con una identidad distinta de la de sus integrantes y que cuando actúa, la conducta se entiende como cometida por un grupo no por un individuo o unos individuos aislados; (3) grupos que cometen conductas muy graves, es decir, grupos que cometen delitos caracterizados por causar un grave daño social, por hacer uso generalizado de la violencia, por atacar la institucionalidad y poner en riesgo la seguridad de la sociedad y de las personas; y (4) grupos que operan de manera planificada, o sea, grupos que obran en función de un plan criminal.

Estas características de agrupaciones que cometen delitos se predican de formas de criminalidad colectiva como el crimen organizado, el terrorismo o incluso los crímenes cometidos por agentes del Estado, por ello las formas de imputar responsabilidad penal en delitos cometidos por grupos criminales con estas características se utilizarán para explicar cómo se puede imputar responsabilidad penal por delitos cometidos por grupos de delincuencia organizada, sin distinguir que se hable de GDO o de GAO, pues, como ya lo hemos explicado, los GAO son también grupos de delincuencia organizada.

Antes de referirnos a las maneras de imputar responsabilidad penal explicaremos unos contenidos doctrinales de una disciplina relacionada con el derecho penal ordinario, como lo es el derecho penal internacional, pues en esta disciplina se suelen estudiar maneras de responsabilizar penalmente a personas por la comisión de conductas criminales similares a las cometidas en grupos de delincuencia organizada, y los contenidos que estudiaremos serán provechosos al momento de hablar de la atribución de responsabilidad penal de los delitos cometidos por grupos de crimen organizado.

\subsection{Aportes del derecho penal internacional}

El derecho penal internacional (en adelante, DPI) es una disciplina cuyo objeto de conocimiento son crímenes graves, sistemáticos, generalizados, que se realizan en una organización, en desarrollo de un plan común y de manera organizada y coordinada ${ }^{58}$. Estos crímenes se ejecutan por organizaciones ${ }^{59}$ cuyos líderes o integrantes de rangos

58 Klaus Marxen. "Intervención en un injusto sistemático grave. Consideraciones sobre una teoría jurídicopenal internacional del delito", en Autores, partícipes y superiores en la justicia internacional, Yesid Reyes Alvarado (coord.), Bogotá, Universidad Externado de Colombia, 2018, p. 35.

59 Yesid Reyes Alvarado. "Formas de intervención delictiva en el derecho penal internacional. A manera de estudio preliminar", en Autores, partícipes y superiores en la justicia internacional, Yesid Reyes Alvarado (coord.), Bogotá, Universidad Externado de Colombia, 2018, pp. 16 y ss. 
altos y medios-altos son quienes gestan el plan criminal para que los rangos medios y de base ejecuten las conductas previstas ${ }^{60}$. Esto dificulta la atribución de responsabilidad y persecución penal de los rangos altos porque quienes intervienen en la ejecución de los delitos suelen ser sujetos reemplazables y de poca importancia para la organización.

Lo anterior puede verse recreado gráficamente en un supuesto en el que un genocida de alto rango en una organización pretende matar a un grupo de ciudadanos por su pertenencia étnica y crea un campo de exterminio con ese fin, conduce allí las víctimas, implementa la infraestructura necesaria para exterminar personas, encierra en cámaras de exterminio a las víctimas y le ordena a un subalterno que active el mecanismo diseñado para cometer la monstruosidad. Es claro que el genocida que ideó el exterminio no intervino en la ejecución del grave crimen, sino que realizó aportes en los actos preparatorios de las muertes, pero sin duda consideramos que el principal responsable de la monstruosidad y quien merece mayor represión penal será quien implementó el mecanismo de exterminio y no lo ejecutó.

En un sistema que solo se enfoca en la conducta individual no se le imputaría responsabilidad penal a quien merece mayor castigo (al genocida de alto rango) sino al sujeto ejecutor que siguió la orden de exterminio, o en el mejor de los casos el genocida de alto rango solo se le atribuiría responsabilidad como interviniente secundario o de menor importancia (partícipe). Esto a todas luces encierra una injusticia, por ello es preferible prescindir de un sistema de imputación que se centre únicamente en la conducta individual del ejecutor de un delito para perseguir penalmente a quien debe ser perseguido, con independencia de que hubieran actuado o no en la ejecución del delito, pues hay ocasiones en que las órdenes de cometer delitos o las omisiones de evitarlos por parte de los altos rangos en una organización criminal son tanto o más determinantes que algunos aportes de los ejecutores ${ }^{61}$.

Conforme a lo anterior, consideramos que deben replantearse los criterios de imputación de las conductas punibles para tener en cuenta no solo la ejecución de la conducta, sino el conocimiento de los sucesos, la jerarquía y capacidad de mando de miembros de la organización, el nivel de planeación de los hechos y la obligación de evitar delitos que les asiste a ciertos integrantes del grupo organizado, esto para atribuir responsabilidad penal a más integrantes de una organización criminal ${ }^{62}$, teniendo en cuenta, claro está, la gravedad de los aportes a la comisión de los delitos.

60 Joachim Vogel. "Responsabilidad individual en el derecho penal internacional. A la vez una aportación a los modelos de regulación de la intervención”, en Autores, partícipes y superiores en la justicia internacional, Yesid Reyes Alvarado (coord.), Bogotá, Universidad Externado de Colombia, 2018, p. 70.

61 Thomas Weigend. "Consideraciones sobre la responsabilidad del superior en el derecho penal internacional”, en Autores, partícipes y superiores en la justicia internacional, Yesid Reyes Alvarado (coord.), Bogotá, Universidad Externado de Colombia, 2018, p. 150.

62 Ibíd.,p. 71. 
En el DPI podemos encontrar ideas que nos ayudan a encontrar criterios de imputación justos para los delitos cometidos por grupos de criminalidad organizada como los conceptos de máximos responsables, plan criminal común y doble imputación.

\subsubsection{Concepto de "máximos responsables"}

En las organizaciones criminales, o en las estatales que actúan como criminales, se cometen conductas delictivas en las que intervienen distintos miembros de la organización o terceros que financian, colaboran o asesoran el actuar criminal de la organización, entre estos intervinientes se encuentran los que son catalogados en el DPI como máximos responsables. Si bien el concepto de "máximos responsables" se refiere a un criterio político-criminal para seleccionar y priorizar el ejercicio de la acción penal y no es una categoría jurídica o dogmática ${ }^{63}$, en nuestro país se han hecho intentos para determinar el concepto de máximos responsables como una categoría determinada o determinable.

La Corte Constitucional indicó que “el concepto de máximo responsable no se identifica con el de jefe del grupo o bloque, como se ha entendido incorrectamente [...]. El máximo responsable es aquella persona que tiene un rol esencial en la organización criminal para la comisión de cada delito, es decir, que haya: dirigido, tenido el control o financiado la comisión de los delitos de lesa humanidad, genocidio y crímenes de guerra cometidos de manera sistemática" ${ }^{64}$.

Por su parte, la Fiscalía General de la Nación en su Directiva 1 de 2012 señaló que se considera máximo responsable "[1] aquel que dentro de la estructura de mando y control de la organización delictiva sabía o podía prever razonablemente la perpetración de crímenes en desarrollo de los planes operativos; y [2] de manera excepcional, se trata de aquellas personas que han cometido delitos particularmente notorios, con independencia de la posición que ocupaban en la organización delictiva" 65 . Este criterio se amplió con la Directiva 2 de 2015, que dijo que se considera máximos responsables a "aquellas personas que, independientemente de la posición que ocupaban en la estructura delictiva, han cometido o tienen responsabilidad directa en la comisión de delitos particularmente graves" 66 .

También en la doctrina nacional se ha dicho que "el parámetro del máximo responsable es un criterio ascendente que permite incluir a quien haya tenido una intervención

63 Iván González Amado. "El concepto de máximos responsables”, en Memorias de la XXXVIII jornadas internacionales de derecho penal: justicia negociada, justicia transnacional y crimen organizado, Bogotá, Universidad Externado de Colombia, 2017, p. 52.

64 Corte Constitucional, sentencia C-579 de 2013.

65 Fiscalía General de la Nación, Directiva 1 de 2012.

66 Fiscalía General de la Nación, Directiva 2 de 2015. 
delictiva en el delito y también a otras personas en virtud de criterios como el de la responsabilidad del superior o el de dominio de aparato organizado de poder" 67 .

De lo anterior se observa que el concepto de "máximos responsables" se utiliza en el DPI como un criterio para seleccionar a quiénes se judicializa e imputan conductas globales por merecer un reproche penal más grave.

Aunque este criterio no se puede aplicar en el derecho ordinario interno para seleccionar o priorizar el ejercicio de la acción penal, porque el Estado está obligado a perseguir penalmente a todos los responsables de todos los delitos que se cometan ${ }^{68}$, sí se puede utilizar para determinar quiénes deberían ser considerados intervinientes principales en la comisión de delitos (autores) y quiénes intervinientes secundarios por no reunir las características de los máximos responsables, esto para reprimir penalmente con mayor gravedad a los intervinientes principales, con menor gravedad a los intervinientes secundarios y no reprimir penalmente a quienes realizan aportes insignificantes.

Con todo lo anterior, consideramos que para respetar el principio de legalidad vigente en nuestro Estado es indefectiblemente necesario determinar en la ley quiénes son intervinientes principales según el concepto de "máximos responsables" y a quiénes se podría considerar intervinientes secundarios.

\subsubsection{Plan criminal común}

Generalmente los hechos constitutivos de crímenes propios del DPI obedecen a un plan criminal común, es decir, son conductas ceñidas, en la medida de lo posible, a un plan determinado para cometer un delito grave o conducta colectiva o global ${ }^{69}$. Este plan es un factor de cohesión para unir los aportes o conductas individuales hechas por los miembros de una organización que conforman una conducta colectiva o hecho total ${ }^{70}$; y para determinar cuándo nos encontramos ante una conducta que tenga el sentido de hacer parte de una conducta colectiva imputable a la organización y cuándo ante una conducta aislada imputable solo a quien la ejecuta y no a la organización ${ }^{71}$.

67 Elena Suárez Díaz y Ernesto Velasco Chaves. "Máximos responsables”, en Justicia transicional: verdad y responsabilidad, Gerardo Barbosa, Carlos Bernal y Andrés Rolando Ciro Gómez (eds.), Bogotá, Universidad Externado de Colombia y Ejército Nacional de Colombia, 2016, p. 265.

68 Constitución Política, artículo 250.

69 Antonio Cassese. Los límites de la responsabilidad penal individual bajo la doctrina de la empresa criminal común, Bogotá, Universidad Externado de Colombia, 2016, p. 13.

70 Kai Ambos. ¿Cómo imputar a los superiores crímenes de los subordinados en el derecho penal internacional?, Bogotá, Universidad Externado de Colombia, 2008, p. 160.

71 Antonio Cassese. Ob. cit., p. 15. 


\subsubsection{Doble imputación}

La doble imputación es una figura usada primigeniamente en el DPI en contextos de macrocriminalidad y delincuencia grave, sistemática y generalizada, y fue prevista en sus inicios para imputar responsabilidad penal a los jefes y superiores jerárquicos de los grupos que cometían los más graves delitos de la segunda guerra mundial y a otros miembros de las organizaciones a quienes les cupiera reproche penal por la gravedad de sus acciones ${ }^{72}$. El objetivo de esto era calificar a quienes se imputaría como máximos responsables de los delitos cometidos dentro de la organización.

En esta clase de delitos se identifican conductas individuales distantes en tiempo y lugar, pero con rasgos comunes de articulación o patrones de criminalidad que se pueden entender como aportes de una conducta colectiva mantenida en el tiempo e imputable a la organización criminal, independientemente de que se ejecuten por distintas personas.

Estas conductas globales se imputan a la organización criminal para que, después de ello, se identifique a los miembros que tienen roles importantes en la organización que hubieran tenido la oportunidad de conocer la conducta global cometida e impedirla y a los miembros que tuvieron injerencia significativa en la comisión de la conducta global de acuerdo a los aportes que tuvieron en la comisión de los hechos, esto para identificarlos como máximos responsables por la comisión de la conducta global.

Un ejemplo de esto sucede cuando ocurren varios homicidios y, según las características y los patrones de criminalidad de estos, se puede determinar que fueron aportes individuales a una conducta global de genocidio imputable a una organización criminal. Después de determinar eso, se observan los roles de determinados integrantes de la organización criminal y los aportes que se tuvieron en la comisión de la conducta global de genocidio para imputarle la conducta a título de máximos responsables ${ }^{73}$.

\subsection{Teoría del dominio del hecho}

Como lo anunciamos con anterioridad, la teoría que postula que la función de la pena es la prevención general negativa o por intimidación enfoca su atención en los hechos voluntarios de los seres humanos, es decir, en procesos mentales y físicos compuestos por una fase interna en la que la persona se representa una forma de actuar, sea imprudente o dolosa, y una fase externa en la que se lleva a cabo en el mundo físico la fase interna y se concreta en un comportamiento voluntario ${ }^{74}$.

72 Kai Ambos. Ob. cit., p. 74.

73 Eduardo Montealegre. Conferencia del IX conversatorio de la jurisdicción constitucional. Diálogo constitucional para la paz, Medellín, 2013, disponible en [https:/www.youtube.com/watch?v=Y5 QnSuVS8o0\&list=WL\&index $=12 \& \mathrm{t}=0 \mathrm{~s}]$.

74 Teddy Enrique Llanos. De las estructuras jerárquicas de poder en el derecho penal colombiano, Bogotá, Ediciones Doctrina y Ley, 2015, pp. 13 y 14. 
Es entendible que, partiendo de la teoría de la función de la prevención general por intimidación, se tenga como autor de estas conductas a quien lleve a cabo o domine las acciones u omisiones voluntarias o, por decirlo de manera más genérica, los comportamientos voluntarios.

De esto se desprende que el criterio para atribuir responsabilidad penal sea la teoría del dominio del hecho, pues esta teoría intenta determinar a quién le es atribuible una conducta por ser el autor de ella y de qué forma se puede distinguir quién es autor y quién partícipe en la comisión de un delito dependiendo de factores como la calidad del aporte realizado y el componente subjetivo del interviniente ${ }^{75}$. De esta manera, no solo es autor quien realiza de manera directa, inmediata o de propia mano la conducta descrita en el tipo penal, sino que también es autor el sujeto que tiene el control, el manejo o la disposición de la ejecución del delito y en quien concurren las circunstancias especiales del sujeto activo del delito descrito en el tipo penal ${ }^{76}$.

El dominio del hecho se puede ejercer de tres formas: (1) dominando la acción, o sea, cometiendo directamente la conducta punible (autoría directa); (2) teniendo el dominio funcional del delito, o sea participando en la ejecución del delito concertando un plan para llevar a cabo el delito, acordando una división del trabajo para ejecutar el delito y realizando un aporte esencial en la ejecución del delito (coautoría); y (3) teniendo un dominio sobre la voluntad de quien interviene en la ejecución del hecho punible (autoría mediata) ${ }^{77}$.

\subsubsection{Autoría mediata}

En este trabajo resulta útil referirnos al dominio del hecho por dominio de la voluntad o autoría mediata y no tanto al dominio de la acción (autoría directa), pues en los delitos cometidos por grupos de crimen organizado no hay mayor dificultad para atribuir responsabilidad penal a quien ejecuta el delito, distinto a lo que ocurre cuando se intenta atribuir responsabilidad penal a sujetos que intervienen de manera esencial en el delito sin participar en la ejecución, como sucede con los jefes de las bandas criminales que ordenan la comisión de graves delitos desde un despacho.

Tampoco nos referiremos al dominio del hecho por dominio funcional o coautoría debido a que en la teoría del dominio del hecho esta forma de intervención requiere un aporte esencial del interviniente en la ejecución del delito y tampoco hay mayor dificultad para imputar una conducta a los sujetos que intervienen como coautores en

75 Alberto Hernández Esquivel. “Autoría y participación”, en Lecciones de derecho penal, parte general, cit., pp. 267 y ss.

76 Gustavo Balmaceda Hoyos. Estudios de derecho penal parte general, Bogotá, Ediciones Nueva Jurídica y Universidad de La Sabana, 2015, pp. 364 y ss.

77 Alberto Hernández Esquivel. Ob. cit., pp. 269 y ss. 
la ejecución del hecho. No desconocemos que nuestra Corte Suprema de Justicia en ocasiones ha exigido la participación del interviniente principal en la ejecución del hecho para que se configure la coautoría ${ }^{78}$ y en otras ocasiones ha manifestado que no se requiere de un aporte del interviniente principal en la ejecución del delito para que se configure la coautoría ${ }^{79}$; sin embargo, en esta última postura no hay aplicación de la teoría del dominio del hecho, como se explicará más adelante.

En este trabajo pondremos nuestra atención en la teoría de la autoría mediata, que es una construcción teórica para atribuir la comisión de una conducta punible a título de autor a una persona que no realizó ningún aporte en la ejecución de ella, lo anterior atendiendo a que actúa por intermedio de otra persona.

Esta teoría tiene como autor a quien domine la voluntad necesaria para llevar a cabo la ejecución de un delito, pero voluntad de la conducta en sentido normativo, no en sentido sicológico, es decir, la voluntad de cometer una conducta con relevancia penal y no un hecho avalorado o, en términos más funcionalistas, la decisión de crear o aumentar un riesgo jurídicamente desaprobado y la capacidad de decidir si se materializa o no dicho riesgo ${ }^{80}$; verbigracia, si un ladrón le pide a otra persona que le alcance un objeto diciéndole que es suyo, pero en realidad es ajeno, el ladrón está valiéndose del ejecutor no doloso para cometer un delito de hurto, pero en ningún momento está eliminando la voluntad sicológica del ejecutor para recoger el objeto y llevarlo a un destinatario determinado.

El dominio de la voluntad en la autoría mediata se puede realizar cuando el autor mediato o dueño de la voluntad actúa a través de otro sujeto aprovechándose de que ese otro sujeto se encuentra (1) en estado de error, (2) coaccionado, (3) con disminución volitiva o a (4) través de un aparato organizado de poder ${ }^{81}$. En los delitos cometidos por grupos de crimen organizado se acude a la teoría de la autoría mediata por utilización de aparatos organizados de poder para imputar las conductas a título de autor a los jefes de las organizaciones criminales ${ }^{82}$.

78 Corte Suprema de Justicia, Sala de Casación Penal, sentencia del 5 de octubre de 2006, rad. n. ${ }^{\circ} 22358$; también, Corte Suprema de Justicia, Sala de Casación Penal, sentencia de casación del 21 de agosto de 2003, rad. n. ${ }^{\circ}$ 19213; y Corte Suprema de Justicia, Sala de Casación Penal, proceso 27677, 2 de diciembre de 2008.

79 Corte Suprema de Justicia, Sala de Casación Penal, sentencias de casación del 7 de marzo de 2007, rad. n. 23825 (caso de la Masacre de Machuca), Corte Suprema de Justicia SP1432-2014, rad. n. ${ }^{\circ}$ 40214, Corte Suprema de Justicia, Sala de Casación Penal, 12 de febrero de 2014, del 8 de agosto de 2007, rad. n. 25974 (caso Yamid Amat), y Corte Suprema de Justicia, Sala de Casación Penal, 12 de septiembre de 2007, rad. n. 24448 (Masacre de La Gabarra).

80 Alberto Suárez. Ob. cit., pp. 276 y 283.

81 Gustavo Balmaceda. Ob. cit., pp. 370 y ss.

82 Claus Roxin. "Problemas de autoría y participación en la criminalidad organizada", en Revista Penal, n. ${ }^{\circ}$ 2, Huelva, Universidad de Huelva, 1998, p. 61. 
Esta teoría parte de la existencia y utilización de una organización estructurada jerárquicamente en la que los líderes o jefes del grupo dan órdenes categóricas de cometer delitos y los subordinados que reciben dichas órdenes las ejecutan o son reemplazados por subordinados que sí cumplan las órdenes, incluso cuando no existiese ningún contacto o comunicación directa con el superior que da la orden ${ }^{83}$.

Esto sucede debido a que el superior jerárquico que ordena es el dueño de la voluntad o quien tiene la decisión de que se cometa el delito, pues, como ya se indicó, el dueño de la voluntad desde el punto de vista normativo es el autor mediato del delito, sin perjuicio de que a la persona que ejecute la orden del superior se le impute la comisión del delito como autor directo. Para explicar mejor esto se precisarán los requisitos contextuales de esta figura que, según lo dicho hasta el momento, están presentes en los grupos de criminalidad organizada:

Aparato organizado de poder. Para que se configure este tipo de autoría mediata debe existir una estructura organizada jerárquicamente y con identidad propia en la que los rangos altos pueden dar órdenes a los rangos medios y a los de base y a su vez los rangos medios pueden dar órdenes a los de base o transmitir las órdenes de los rangos altos a los ejecutores de base ${ }^{84}$.

Poder de mando. Debe existir relación jerárquica entre el autor mediato y el ejecutor, pues este tipo de autoría mediata no parte de una relación de colegas que llegan a un acuerdo sino de una orden que un superior da a un subordinado. No obstante lo anterior, el hecho de que haya un rango intermedio entre el autor mediato y el ejecutor no implica que no pueda haber relación de mando entre estos, inclusive puede suceder que el jefe del aparato de poder dé la orden al rango medio de que se cometa un delito y el rango medio dé la orden al ejecutor de que se cometa el delito y el ejecutor, que es un militante de base, cometa el delito, en este supuesto el jefe del grupo y el rango medio pueden figurar como autores mediatos y el ejecutor como autor directo ${ }^{85}$.

Apartamiento del derecho. Todo delito implica un apartamiento del derecho por parte de la persona que lo comete. En este caso la decisión de apartarse del derecho no es solamente del ejecutor del delito sino de la organización por medio de la cual se comete el delito. Esto ocurre claramente en las estructuras de crimen organizado. Sin embargo, no se presenta solo en grupos al margen de la ley, pues hay organizaciones

83 Claus Roxin. Derecho Penal, Parte General, tomo II: Especiales formas de aparición del delito, traducción y notas de Diego Manuel Luzón Peña, José Manuel Paredes Castañón, Miguel Díaz y García Conlledo y Javier de Vicente Remesal, Madrid, Civitas-Thomson Reuters, 2014, p. 111.

84 Claus Roxin. Problemas de autoría..., cit., p. 114.

85 Claus Roxin. "Dirección de la organización como autoría mediata", Manuel Abanto (trad.), en Anuario de Derecho Penal y Ciencias Penales, t. 62, Madrid, Ministerio de Justicia de España, 2009, p. 60. 
legales que se pueden separar parcialmente del derecho, en estos casos también se puede configurar la autoría mediata ${ }^{86}$.

Ejecutores reemplazables. Se puede afirmar que el autor mediato tiene el dominio del hecho porque, aparte de tener mando, tiene a su disposición una gama de ejecutores que pueden llevar a cabo el delito y, en caso de que alguno de los ejecutores se niegue a cometerlo, se pueda reemplazar con facilidad por alguien que sí lo cometa. Por eso, aparte de existir la posibilidad de reemplazar al ejecutor que no realice la conducta, surge indispensable la existencia de un número suficiente de eventuales ejecutores para asegurar que la comisión del delito no se frustre, pues si los eventuales ejecutores pudieran frustrar la comisión del delito, el autor mediato dejaría de tener el dominio del hecho ${ }^{87}$.

Disposición del ejecutor. Debe haber condiciones circunstanciales que aseguren que el ejecutor, a pesar de tener la libertad de no cometer delitos, se decida a cumplir los mandatos criminales como la identidad de intención del ejecutor y del autor mediato $^{88}$, la reverencia del ejecutor a los mandos superiores, la interiorización de los propósitos del grupo organizado y el convencimiento de que si no acata las órdenes otra persona lo hará ${ }^{89}$.

Aunque esta teoría ha tenido bastante éxito, nuestra legislación tiene una redacción que genera resistencia para este tipo de autoría debido a que el artículo 29 del CP dice: "[...] Es autor quien realice la conducta punible por sí mismo o utilizando a otro como instrumento [...]", mientras que la legislación utilizada como referencia para hablar de la autoría mediata por aparatos organizados de poder por Roxin, el Código Penal Alemán (Strafgesetzbuch), dice en su artículo 25: "Autoría. Se castiga como autor a quien cometa el hecho punible por sí mismo o a través de otro. [...]"90.

Esto indica que la legislación que sirvió de base para idear esta forma de autoría no exige la utilización de una persona como “instrumento" en la comisión de un delito, mientras que la autoría mediata en nuestra legislación, sin tener la necesidad de precisar, estableció que el autor mediato tiene que "utilizar" al ejecutor, no valerse de los aportes de él, y tiene que tratar al ejecutor como un "instrumento", no como una persona plenamente libre y responsable. Estas precisiones hechas en la ley (ejecutor debe ser instrumento y no persona plenamente libre y responsable; y ejecutor debe ser utilizado y no apoyar de manera autónoma) no pueden resultar intrascendente o

86 Ibíd., p. 60.

87 Claus Roxin. Derecho Penal, Parte General, cit., p. 106.

88 Héctor Olasolo. Introducción al derecho internacional penal, Bogotá, Universidad del Rosario, 2015, p. 102.

89 Claus Roxin. Dirección de la organización..., cit., p. 63.

90 Claudia López. Código Penal alemán, Bogotá, Universidad Externado de Colombia, 2002, p. 10. 
inoficiosas, por ello no es admisible la importación de esta figura en Colombia ignorando estas precisiones que prevé la ley para la configuración de la autoría mediata.

El propio creador de esta construcción dogmática, Claus Roxin, precisa que "el 'instrumento' que posibilita al sujeto de atrás el cumplimiento de sus órdenes no es solamente (y ni siquiera lo es en la mayoría de los casos) aquel que ejecuta de propia mano la muerte de la víctima. Más bien el verdadero instrumento es el aparato como tal" ", lo cual no coincide con la regulación colombiana, pues en nuestro CP el "instrumento" es la persona que ejecuta la conducta, no el aparato organizado de poder como ocurre con la teoría del profesor Roxin.

Por otra parte, cuando nuestra legislación exige que el ejecutor sea utilizado como un instrumento se entiende que el ejecutor no sea una persona que actúe con plena libertad, sino que actúe siendo instrumentalizado, es decir con libertad y autonomía disminuida de manera significativa, pues si actuara con plena libertad nos referiríamos a un sujeto con toda la capacidad de frustrar la comisión del delito o realizarlo de manera distinta a la prevista en las órdenes del superior jerárquico que ordena el delito y esto es un supuesto muy distinto al de la autoría mediata por aparatos organizados de poder.

No ignoramos que hay doctrinantes nacionales muy autorizados ${ }^{92}$ y pronunciamientos de la Corte Suprema de Justicia ${ }^{93}$ que aceptan que en Colombia exista la posibilidad de utilizar personas como instrumentos plenamente libres y responsables para cometer delitos; sin embargo, consideramos que hablar de "instrumentos plenamente libres y responsables" no solo es una contradicción terminológica, sino una construcción argumentativa para imputar como autor a un sujeto por la acción cometida por otra persona, sacrificando los principios de legalidad y de responsabilidad individual por importar una teoría extranjera, pues el artículo 29 del CP no da cabida a la figura de la autoría mediata por aparatos organizados de poder, que si cabe en la legislación alemana.

Aparte de esto, tampoco es claro que esta forma de autoría mediata se adscriba a la teoría del dominio del hecho por dominio de la voluntad, pues en esta figura una persona con libre albedrío da una orden y otra persona con libre albedrío acata la orden o es reemplazada por otra persona con libre albedrío que acata la orden o es reemplazada por otra persona con libre albedrío que acata la orden o es reemplazada por otra persona con libre albedrío que acata la orden o es reemplazada por otra persona con libre albedrío... y así sucesivamente, hasta que se llegue al último de los hombres reemplazables que tiene libre albedrío y recibe la orden, y puede acatarla o no acatarla.

91 Claus Roxin. Dirección de la organización..., cit., pp. 57 y 58.

92 Alberto Suárez. Ob. cit., p. 334.

93 Corte Suprema de Justicia, Sala de Casación Penal, sentencia del 23 de febrero de 2010, radicación

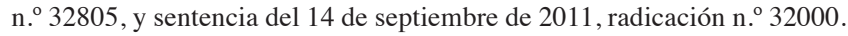


La particularidad de tratar con personas que tienen libre albedrío consiste en que no se sabe de qué forma van a actuar en el futuro y siempre habrá incertidumbre sobre su actuación, es decir, no hay dominio del hecho por parte del hombre de atrás, pues, aunque no suceda muy seguido que los militantes de un aparato organizado de poder se separen de lo ordenado por sus superiores, sí es posible que esto ocurra, y serían casos razonablemente posibles que demuestran que así existan aparatos organizados de poder con las condiciones que hemos indicado, no es seguro que en ellos siempre haya un dominio de la voluntad por parte del superior jerárquico; de hecho, si reconociéramos que por la naturaleza de la organización hay una seguridad casi garantizada de que el ejecutor obedezca, nos encontraríamos frente al supuesto de un sujeto coaccionado, no ante el supuesto de un sujeto libre, lo cual haría innecesaria la categoría de autoría mediata por aparatos organizados de poder, pues hay autoría mediata por coacción, por error y por disminución volitiva.

Esto muestra que lo que entendemos por autoría mediata por aparatos organizados es solamente un aporte importante en los actos preparatorios que realiza un superior jerárquico y que, por asuntos de contexto, asegura una gran posibilidad de realización del delito, pero esto no es una manifestación del dominio del hecho por dominio de la voluntad del hombre de atrás que permita calificar como autor a la persona que ordena la comisión de un delito, pues el ejecutor nunca pierde la voluntad normativa ni el dominio del resultado delictivo como sí sucede cuando se instrumentaliza a una persona que actúa en error, bajo coacción o con disminución volitiva.

Por lo anterior concluimos que con la autoría mediata por aparatos organizados de poder tampoco encontramos una solución satisfactoria para resolver el problema de este trabajo, que es encontrar una forma adecuada de imputar una conducta punible cometida por una organización criminal a un miembro de la agrupación de crimen organizado que no intervino en la ejecución del delito, pero actuó como interviniente principal.

\subsection{El papel de los partícipes en la teoría del dominio del hecho}

La teoría del dominio del hecho no es una teoría que desconozca otras formas de intervención secundarias, accesorias y distintas a la autoría, como la complicidad o la determinación. Estas formas de intervención también están presentes en nuestro ordenamiento y permiten imputar a un jefe de banda criminal una conducta cometida por un grupo de crimen organizado, aunque no hubiera intervenido en la ejecución de un delito, lo cual indica que aparentemente no habría vacíos de impunidad para esta clase de intervinientes.

En nuestro CP, artículo 30 inciso 3, se encuentra regulada la figura de la complicidad de la siguiente manera: "Quien contribuya a la realización de la conducta antijurídica o preste una ayuda posterior, por concierto previo o concomitante a la misma, 
incurrirá en la pena prevista para la correspondiente infracción disminuida de una sexta parte a la mitad".

La complicidad se entiende como una contribución al autor de un delito que incrementa el riesgo de realización del resultado ${ }^{94}$ y se puede realizar durante la ejecución, en los actos preparatorios o con posterioridad a la ejecución del delito, siempre y cuando el aporte posterior a la ejecución se hubiera previsto con anterioridad a la ejecución del delito y tuviera una inescindible relación con él ${ }^{95}$. En este orden de ideas, resulta imposible negar que el aporte de un superior jerárquico de una organización delincuencial puede llegar a ser considerado una contribución al ejecutor de un delito, incluso sin que tomara parte en la ejecución, solo que a un cómplice se le atribuye responsabilidad penal propia de un interviniente secundario y por ello se le impone una pena menor, mientras que los aportes de un superior jerárquico no siempre son secundarios y en ocasiones tienen igual o más importancia que muchos aportes que se realizan en la ejecución, aun cuando no se concretan en la ejecución del delito.

Cuando se imputa al jefe de una organización criminal que ordena cometer un secuestro la correspondiente conducta como cómplice, este no queda en la impunidad, sin embargo, sí se le atribuye responsabilidad penal como si fuera un interviniente de segundo orden y se le impone una pena inferior a la que merecería. Debemos recordar que una de las teorías de la función de la pena que hemos estudiado (la retribución) parte del supuesto de que la pena con que se debe castigar a los responsables de un delito debe ser justa y proporcional de acuerdo con la naturaleza de la conducta, por ello resulta insatisfactoria la solución de atribuirle responsabilidad penal como cómplice a un jefe de organización criminal que hubiera realizado aportes que merecen un reproche penal equivalente al de un interviniente de primer orden (autor).

En el mismo artículo 30 del CP, pero esta vez en el inciso 2, hay una figura prevista en los siguientes términos: "Quien determine a otro a realizar la conducta antijurídica incurrirá en la pena prevista para la infracción”. Esta construcción normativa se conoce como la determinación y también posibilita atribuir la conducta a título de partícipe a un interviniente que, sin actuar en la ejecución, debería responder penalmente por los hechos del ejecutor, pero a diferencia del cómplice, al determinador se le impone la misma pena que al autor.

La Corte Suprema de Justicia ha utilizado esta figura para atribuir responsabilidad penal a sujetos que no intervienen en la ejecución de un delito cometido por una organización criminal ${ }^{96}$. Esta figura se usa cuando un interviniente, por medio de dádiva para convencer, por promesa remuneratoria o de cualquier beneficio, por asesoría,

94 Alberto Hernández. Ob. cit., p. 296.

95 Corte Suprema de Justicia, Sala de Casación Penal, radicación n. ${ }^{\circ} 41758$, del 18 de mayo de 2016.

96 Corte Suprema de Justicia, Sala de Casación Penal, radicación n. 32672 del 3 de diciembre de 2009. 
por amenazas o por órdenes, consigue que el autor tome la decisión de cometer el delito $^{97}$, pero se debe aclarar que la dádiva, la orden, la promesa, las amenazas o la asesoría deben ser la causa por la que el autor toma la decisión de cometer el delito, no una simple contribución para reforzar la voluntad del autor de cometer el delito, pues en este último caso nos encontraríamos ante una simple complicidad por refuerzo de la voluntad que no es un aporte igual de decisivo y no ameritaría que la pena del determinador fuera igual que la del autor ${ }^{98}$.

La doctrina mayoritaria y la jurisprudencia consideran que el determinador es un partícipe que hace nacer en el autor la idea y la decisión de cometer el delito ${ }^{99} \mathrm{y}$, por tanto, siempre debe tener una relación inmediata con la persona que comete el delito (autor) ${ }^{100}$. Esto se debe a que una de las acepciones del verbo rector de la determinación (determinar) es "Hacer que alguien decida algo" 101 y que regulaciones que han influido a la normatividad colombiana, como la española, prevén una figura equivalente a la determinación en su Código Penal de la siguiente forma:

Artículo 28. Son autores quienes realizan el hecho por sí solos, conjuntamente o por medio de otro del que se sirven como instrumento.

También serán considerados autores:

(a) Los que inducen directamente a otro $u$ otros a ejecutarlo $[\ldots]^{102}$.

Sin embargo, al buscar otras acepciones del verbo rector determinar en el diccionario oficial de la RAE encontramos que determinar también es "Ser causa de que algo ocurra o de que alguien se comporte de un modo determinado"103.

Si nos adscribimos a la primera definición del verbo rector determinar, no podríamos utilizar en muchas oportunidades la figura de la determinación para atribuir delitos a integrantes de un grupo de crimen organizado, pues solo se podría atribuir conductas a título de determinador a quien convence al autor material a cometer un delito.

97 Alberto Hernández Esquivel, José Manuel Díaz Soto y Carlos Arturo Gómez Pavajeau. “Autoría y participación", en Lecciones de derecho penal, parte general, 3. a ed., Bogotá, Universidad Externado de Colombia, 2019, p. 302.

98 Federico Londoño Mesa. "Concurso de personas en la conducta punible”, en Derecho penal, parte general - fundamentos, Diego Araque (coord.), Medellín, Universidad de Medellín, 2009, p. 573.

99 Corte Suprema de Justicia, sentencia de única instancia de la Sala de Casación Penal del 26 de octubre de 2000, además de los anteriores autores citados.

100 Federico Londoño. Ob. cit., p. 573.

101 Diccionario de la Real Academia Española, disponible en [https://dle.rae.es/?w=determinar].

102 Ley Orgánica 10/1995 de España.

103 Diccionario de la Real Academia Española, cit. 
Verbigracia, un jefe de una organización criminal determina a un miembro de rango medio para que cobre unas extorsiones a la población, el integrante de rango medio le ordena a un militante de base del grupo que vaya casa por casa amenazando y cobrando la extorsión que le solicitó el jefe de la organización y el esbirro lo hace. En este caso no podría ser determinador el jefe del grupo, a pesar de ser la persona que tuvo la idea y dispuso que su organización cobrara una extorsión, porque no estaría determinando al autor material a cometer la extorsión, sino que estaría determinando a otro para que este a su vez determine a otro a cometer el delito.

No obstante, si acogemos la segunda acepción de la RAE del verbo rector determinar, sí podemos imputar la conducta al jefe del grupo como determinador, pues, si consideramos que determinar es "ser causa de que algo ocurra o de que alguien se comporte de un modo determinado", cuando el jefe del grupo ordena al rango medio cometer una extorsión y este le ordena a un ejecutor de base que cobre la extorsión, el jefe del grupo y el rango medio estarían haciendo que el esbirro cobre las extorsiones, por tanto ambos serían determinadores, independientemente de que el jefe de la organización no le hubiera dado la orden directamente al ejecutor.

Esta postura no es la más común ni la más usual, sin embargo, en el año 2018 la Corte Suprema de Justicia profirió una decisión mediante la cual abrió la posibilidad de entender la determinación de esta manera y la llamó "determinación en cadena":

La instigación a su vez puede ser directa y en cadena, como ocurre o puede suceder cuando entre el autor y el instigador media la intermediación de otro instigado. En relación con esta última posibilidad, el artículo 30 del Código Penal se refiere a la determinación directa, lo cual no excluye la posibilidad de la instigación en "cadena" [...].

Para la Sala, excluir la posibilidad de la denominada determinación en cadena cuando se presenta una relación "mediata" entre el autor material y el determinador inicial, puede conducir a injustificadas lagunas de punibilidad [...].

Aunque nos resulta muy interesante esta forma de concebir la determinación, tenemos que decir que la figura de la determinación tampoco es la solución ideal para imputar a un miembro de un grupo de crimen organizado la conducta realizada por la organización, a pesar de no haber intervenido en la ejecución del hecho punible, pues aunque, a diferencia de lo que ocurre con la complicidad, la determinación implica una pena justa y proporcional de acuerdo al aporte cometido en el delito, pero hace que se impute el delito de la organización a título de interviniente secundario, lo cual acarrea consecuencias sustanciales.

El hecho de que impute un delito como interviniente secundario significa que la punibilidad de la conducta estará supeditada a que no haya causal de justificación 
o atipicidad en la conducta del autor o interviniente principal ${ }^{104}$. Verbigracia, si un determinador, sin conocer la situación de un eventual ejecutor, le ordena a este cometer un delito y se demuestra que el autor estuvo actuando en estado de necesidad o legítima defensa, se dejará en impunidad al determinador, así el determinador no esté actuando de manera justificada. Esto propicia que el determinador tenga un tratamiento punitivo benévolo e inmerecido, a pesar de haber actuado de una forma que amerita un reproche penal severo por parte del Estado, como el que amerita un interviniente principal.

\subsection{Teoría de la intervención}

Como lo explicamos anteriormente, en la teoría de la función de la prevención general positiva de la pena, el derecho penal no se interesa por manifestaciones de la voluntad, sino por infracciones a deberes ${ }^{105}$. Estas infracciones pueden ser a deberes positivos o especiales y a deberes negativos o generales ${ }^{106}$ : los deberes positivos son los deberes que tienen ciertas personas que cuidan la organización de otras personas o intereses institucionales, como los padres o los policías, y los deberes negativos son los deberes que tienen todas las personas.

En los grupos de crimen organizado se cometen delitos por parte de sujetos que no tienen ninguna cualificación especial, ya que solo son delincuentes que infringen los mínimos deberes que se pueden esperar de las personas que viven en sociedad, por ello nos centraremos en las infracciones de los deberes negativos y no en las infracciones a los deberes positivos.

Los deberes negativos consisten en no afectar la esfera de libertades y derechos de los demás y surgen o se vuelven competencia de los ciudadanos de acuerdo con el ejercicio de la libertad de cada quien, es decir, a cada quien le compete obligarse a hacer algo o a abstenerse de hacer algo conforme al ejercicio de su libertad: si una persona crea o aumenta un riesgo no permitido, le compete el deber de revocarlo; y si la persona no ha creado ningún riesgo no permitido, está obligada simplemente a no crear o aumentar riesgos no permitidos ${ }^{107}$.

La infracción a estos deberes comprendidos en el ámbito de competencia de cada quien hace penalmente responsable del resultado lesivo a quien los infringe. Estas son las infracciones que le importan al derecho penal. Es decir, al derecho penal no le

104 Alberto Hernández. Ob. cit., p. 291.

105 Heiko Lesch. Intervención delictiva e imputación objetiva, traducción de Javier Sánchez-Vera, Bogotá, Universidad Externado de Colombia, 1997, p. 31.

106 Günther Jakobs. Injerencia y dominio del hecho, traducción de Manuel Cancio, Bogotá, Universidad Externado de Colombia, 2001,p. 10.

107 Ibíd., p. 12. 
importan las acciones naturales de una persona que mata a otra, sino las infracciones al deber que le compete a una persona de evitar la muerte de otra, ya sea organizándose para no causar muerte a otro o revocando el riesgo de muerte a otro creado o aumentado, reiterando que el ámbito de competencia de deberes se determina de acuerdo con el ejercicio de la libertad u organización de la persona ${ }^{108}$.

Acogiendo esta teoría, el derecho penal deja de interesarse en aportes causales carentes de valoración normativa para interesarse únicamente en infracciones a deberes que tengan sentido delictivo. Por ejemplo, si una persona tiene la intención de matar a alguien, toma un taxi para ir adonde vive la víctima y la mata, el taxista con su aporte contribuyó al injusto, pero no se organizó con sentido de causar muerte sino de trabajar como taxista. En este ejemplo la conducta de manejar un taxi no crea ningún riesgo no permitido (llevar gente en taxi está permitido), por tanto, no hacen competente al taxista de evitar la muerte de la víctima; en cambio, la organización del homicida sí es una conducta con sentido de causar muerte, por eso se hace competente del deber de evitar la muerte de la víctima, y en caso de causar el homicidio, infringiría su deber de evitar la muerte.

El injusto penal puede contar con aportes de distintas personas que tengan un sentido de infringir la norma, en este caso se considera cada aporte como parte de la infracción al deber ${ }^{109}$. Verbigracia, si en el caso anterior el homicida le comenta el plan al taxista y le pide que lo lleve a cometer el delito, si el taxista organiza su libertad y decide llevar al homicida, se hace competente del deber de evitar la muerte por la contribución prestada o por el aumento en el riesgo no permitido, es decir, se hace responsable del deber de no llevar al homicida o, en caso de llevarlo, se hace responsable del deber de revocar el incremento del riesgo evitando que se mate a la víctima, por ello, si se mata a la víctima y se infringe el deber de evitar su muerte, el aporte del taxista y el del homicida (ejecución del homicidio) configurarían una sola infracción al deber o una conducta global.

Es claro que cuando una persona crea o aumenta un riesgo no permitido se hace responsable del deber de evitar el resultado lesivo de ese riesgo revocándolo. Sin embargo, hay otras formas de hacerse competente del deber de evitar un resultado lesivo de acuerdo con la libertad de organización sin necesidad de crear o aumentar riesgos no permitidos. Uno de los ejemplos más comunes es la asunción voluntaria de la administración y custodia de una fuente de riesgo ${ }^{110}$, toda vez que esta asunción voluntaria es una conducta libre que, como toda conducta libre, acarrea responsabilidades.

108 Günther Jakobs. "La intervención delictiva", en Derecho penal y sociedad, tomo II, Eduardo Montealegre (coord.), Bogotá, Universidad Externado de Colombia, 2007, p. 19.

109 Günther Jakobs. Teoría de la intervención, cit., pp. 28 y ss.

110 Jason Andrade. "El delito de omisión”, en Lecciones de derecho penal..., cit., p. 329. 
El deber de evitar resultados lesivos por la administración y custodia de una fuente de riesgo asumida voluntariamente es otro de los deberes que le importan al derecho penal, por eso, cuando una persona incumple el deber de evitar un resultado lesivo habiendo asumido voluntariamente la administración y custodia de una fuente de riesgo, se responsabiliza penalmente por el resultado lesivo, inclusive cuando la conducta la hubiere cometido otra persona, pues en ese caso se debe acumular el aporte del ejecutor consistente en llevar a cabo el resultado lesivo del delito con el aporte del custodio de la fuente de riesgo consistente en no evitar el resultado lesivo.

Un ejemplo: una persona llamada A tiene una fábrica de armas, por ello asume voluntariamente la administración y custodia del personal y los bienes de la fábrica, y escucha que su empleado B quiere hurtar un arma y usarla; si A deja el arma en el cajón del escritorio de B para que este coja el arma y B coge el arma, sale a la calle y es detenido por un policía que le pide permiso para usar arma, A y B serían responsables del delito de porte ilegal de armas de B porque el aporte de A de no evitar que B coja el arma y el aporte de B de coger el arma y salir a la calle conformaron la conducta global de porte ilegal de armas.

El profesor Günther Jakobs, defensor de esta teoría de la intervención, considera que cuando se imputa una conducta global dolosa que cuenta con aportes de varias personas es posible acumular a dicha conducta un aporte culposo ${ }^{111}$. Verbigracia, cuando el señor $\mathrm{X}$ deja descuidadamente un arma en la casa y un invitado llamado Y aprovecha la situación para robar el arma y utilizarla para cometer un homicidio, Jakobs considera que haber descuidado el arma es un aporte de X que se debe acumular al aporte de Y para atribuirles de manera global la conducta de homicidio. Sin embargo, consideramos que esta acumulación de aportes desborda los límites de la responsabilidad individual de la conducta, toda vez que le imputa una conducta dolosa a alguien que solo debe responder por su actuar imprudente y extiende de manera peligrosa las consecuencias de las conductas de unos ciudadanos a otros.

Con la teoría de la intervención se pueden llenar lagunas de punibilidad para imputar conductas delictivas realizadas por grupos de crimen organizado a ciertos integrantes del grupo que no actúan en la ejecución de la conducta, cosa que no se puede hacer con posturas que solamente conciban la conducta como acción individual, verbigracia, un líder de una organización criminal ordena un secuestro desde un escritorio y el secuestro se lleva a cabo por un militante de base del grupo. En este ejemplo, aunque el jefe de la banda no intervino en la ejecución, su forma de organizarse (ordenar el secuestro) lo hacía competente del deber de revocar el riesgo de realización del secuestro y evitarlo, por tanto, de perpetrarse el secuestro, el aporte del jefe del grupo de no evitar el secuestro se acumula con el aporte del ejecutor del 
secuestro para que se responsabilicen penalmente de la conducta global o resultado lesivo (el secuestro).

Otro ejemplo: cuando una persona asume voluntariamente la dirección de un grupo de crimen organizado en el que hay que administrar personal de la organización (delincuentes de base) y bienes de manipulación peligrosa (armas), se hace competente del deber de evitar que estas fuentes de riesgo causen resultados delictivos, por tanto, en el evento de que los integrantes de la organización (por orden del jefe o sin ella) se dispongan a cobrar extorsiones, el jefe de la organización se hace responsable penalmente por no evitar que su personal cometa extorsiones, pues su aporte de no evitar las extorsiones se acumula con el aporte de la ejecución de las extorsiones, ya que el hecho de estar al margen de la ley no excluye el deber de administrar las fuentes de riesgo de tal forma que no se afecte la esfera de libertad ajena.

Aunque la teoría de la intervención tiene el potencial de dar soluciones sistemáticas a casos en los que se necesita imputar una conducta realizada por un grupo de crimen organizado, no es una teoría infalible ni debe acogerse sin crítica, ya que no determina criterios para graduar la importancia del aporte de la intervención, es decir, no diferencia los aportes de autoría y de participación ${ }^{112}$, y esto debería diferenciarse claramente para distinguirlos explícitamente en la ley y no imputar la misma responsabilidad penal a quien realiza un aporte importante y a quien realiza un aporte secundario o uno insignificante en la conducta global. Por otra parte, esta teoría tampoco delimita con precisión cuándo una conducta se puede acumular con otra para conformar un injusto global, pues, como lo indicamos con anterioridad, no consideramos proporcional ni ajustado al principio de responsabilidad individual tener en cuenta los aportes individuales culposos con el fin de acumularlos a conductas globales dolosas para atribuir a todos los intervinientes responsabilidad penal por las conductas dolosas.

\subsection{Propuesta de forma de imputación}

Hemos observado que la teoría del autoría mediata en aparatos organizados de poder trata de dar soluciones al problema de este trabajo de encontrar una manera de imputar a los miembros de grupos de crimen organizado las conductas punibles cometidas por estos grupos; sin embargo, esta teoría no se acomoda a nuestra legislación ni logra determinar si hay dominio de la voluntad en los casos en los que se dan órdenes a sujetos libres y responsables, por ello no se debería tener como una forma de autoría mediata acogida o permitida en nuestro Código Penal.

Por otra parte, advertimos que utilizando las figuras de la complicidad y la determinación se busca solucionar el mismo problema, pero estas figuras califican como

112 Diego Araque y Esteban Vásquez. "Reflexiones sobre la delimitación entre autor y partícipe: pasado, presente y futuro", en Nuevo Foro Penal, n. ${ }^{\circ}$ 91, Medellín, 2018, pp. 146 y ss. 
interviniente secundario a quien puede ser un interviniente principal y permiten lagunas de impunidad por la condición de accesoriedad que identifica a este tipo de figuras. Además de esto, la complicidad no siempre atribuye la responsabilidad penal que merecen ciertos intervinientes y esto se ve reflejado en la pena que se ha de imponer.

También encontramos que la teoría de la intervención de Jakobs permite imputar conductas a quienes no han actuado en la ejecución de un delito, como en el caso de los jefes de grupos de crimen organizado, de manera sistemática y sin lagunas de punibilidad; sin embargo, es una postura muy riesgosa porque extiende de manera exagerada la atribución de responsabilidad penal y no permite la distinción entre aportes principales (aportes de autor) y aportes secundarios (aportes de partícipe), lo cual redunda en una desproporción al momento de graduar la intensidad de la pena o en la inseguridad de la graduación de ella, ya que se le confía esta tarea al arbitrio de un juez y no al criterio del legislador y, en un Estado respetuoso del principio de legalidad, hay que prevenir que los jueces fijen el monto de las penas con una discrecionalidad desmedida.

A pesar de lo anterior, consideramos adecuado adoptar la teoría de la intervención de Jakobs para atribuir responsabilidad a los distintos intervinientes en los delitos cometidos por agrupaciones de delincuencia organizada porque es sistemática y sin inconsistencias, pero proponemos una morigeración en los inconvenientes anunciados $\mathrm{y}$, para este fin, vamos a valernos de los aportes de DPI que explicamos anteriormente, toda vez que esta disciplina conoce un tipo de delincuencia con características similares a las de la criminalidad organizada.

Uno de los aportes a la conducta global cometida por un grupo de crimen organizado es la infracción del deber de evitar un resultado por parte de quien asume voluntariamente la administración y custodia de una fuente de riesgo. Para saber si al integrante del grupo de crimen organizado que asume voluntariamente la administración de la organización criminal le compete o no el deber de evitar un resultado es necesario determinar si el delito fue cometido por la organización que administra, pues si no fue cometido por la organización no le compete el deber de evitar el resultado a quien administra la organización criminal.

Para determinar si el delito corresponde a la organización criminal el DPI utiliza la metodología de la doble imputación y para este fin se verifica si las conductas tienen un patrón de criminalidad que permita inferir que es la organización la que está actuando y que los aportes delictivos corresponden a un plan criminal común.

Acto seguido, se debe determinar quiénes son los integrantes que ocupan roles de administración de la organización criminal y que debían evitar a conducta global y quiénes son los intervinientes que hicieron los otros aportes a la conducta global para acumular los en la conducta global. Es necesario aclarar que para que no ocurran desafueros, como acumular conductas culposas a conductas dolosas para atribuir 
a todos los intervinientes la conducta dolosa, cobra utilidad lo que en DPI se llama "plan criminal común", pues este plan es un factor que articula y da cohesión a los aportes individuales de los intervinientes, debido a que con la correspondencia de los aportes individuales al plan común podemos saber si estos aportes individuales son conductas que integran la conducta delictiva y tienen el sentido de infringir la norma haciendo parte de una conducta global ${ }^{113}$.

Después de esto, se califica la calidad de los aportes y las condiciones de quienes participaron en la conducta global para reputarlos como (1) intervinientes principales (autores), como lo hace el DPI con los máximos responsables; (2) intervinientes secundarios (participes), de acuerdo con la menor importancia del aporte; y (3) intervinientes poco significativos, a quienes no se les haría juicio de atribución de responsabilidad penal, como sucede con quienes no son máximos responsables en el DPI.

En los casos en que a quien administra la organización criminal no le competa evitar el resultado delictivo porque sean resultados imprevisibles, inevitables o no se atribuyan a la organización, se hace el mismo análisis para los intervinientes que participaron en el delito e hicieron aportes a una conducta delictiva global, es decir, se atribuye la responsabilidad a quienes hubieran intervenido en el delito de acuerdo al plan criminal y como se indicó en párrafos anteriores.

\subsection{Aplicación de la propuesta en el ordenamiento interno}

En nuestro CP hay la posibilidad de imputar a los miembros de un grupo de crimen organizado los delitos cometidos por ese grupo según la literalidad del artículo 29, que dice así:

Artículo 29. Autores. Es autor quien realice la conducta punible por sí mismo o utilizando a otro como instrumento.

Son coautores los que, mediando un acuerdo común, actúan con división del trabajo criminal atendiendo la importancia del aporte [...].

Independientemente de que nuestra Corte Suprema tenga pronunciamientos que exigen la participación de los intervinientes en la ejecución de la conducta ${ }^{114}$ y otros

113 Yesid Reyes Alvarado. "Intervención delictiva e imputación objetiva”, en Derecho Penal Contemporáneo, Revista Internacional, n. ${ }^{\circ} 21$, Bogotá, Legis, 2007, p. 17.

114 Corte Suprema de Justicia, Sala de Casación Penal, sentencia del 5 de octubre de 2006, radicación n. . 22358; también, Corte Suprema de Justicia, Sala de Casación Penal, sentencia de casación del 21 de agosto de 2003, radicación n. ${ }^{\circ}$ 19213; y Corte Suprema de Justicia, Sala de Casación Penal, proceso . $^{\circ} 27677,2$ de diciembre de 2008 . 
pronunciamientos que aseguran que no es necesaria la participación de los intervinientes en la ejecución del delito para que se configure la coautoría ${ }^{115}$, podemos decir que la literalidad del artículo 29 no exige ningún tipo de participación en la ejecución del delito por parte de los intervinientes principales para que se configure la coautoría, solo exige (1) común acuerdo, que puede ser previo o concomitante; (2) división del trabajo y (3) un aporte importante, que puede ser en un acto preparatorio o ejecutivo, desde que sea importante.

Visto esto, resulta válido afirmar que la literalidad del artículo 29 del CP da cabida a la teoría intervención en lo atinente a la coautoría, solo que correspondería a la jurisprudencia determinar cuándo nos encontramos ante un aporte importante que amerite calificar al interviniente como autor, cuándo el aporte se tendrá como secundario para calificar al interviniente como partícipe y cuándo se considerará insignificante el aporte para ignorarlo, para este fin recomendamos tener en cuenta los criterios de los que se vale el DPI para determinar quién es máximo responsable.

Este artículo del CP es útil para imputar responsabilidad en delitos cometidos por grupos de delincuencia organizada en casos como cuando un jefe de la banda criminal negocia un cargamento de estupefacientes y le ordena a un sujeto de rango medio que coordine la entrega de cargamento, a su vez este miembro de la organización de rango medio ordena a los miembros de base que materialicen la entrega de los estupefacientes y los militantes de base del grupo entregan el cargamento. En este caso (1) el jefe de la banda hizo un aporte importante, el miembro de rango medio también hizo un aporte importante y los miembros de base que entregaron los estupefacientes también hicieron su aporte importante; (2) todos los intervinientes estuvieron de acuerdo en realizar la entrega de los estupefacientes; y (3) hubo división del trabajo, por tanto, con el artículo 29 es posible imputar los delitos cometidos por la organización criminal a todos los intervinientes de la banda, independientemente de que concurrieran a la ejecución del delito.

Además, en el artículo 25 del CP se establece la posibilidad de configurar la responsabilidad por asunción de una fuente de riesgo de la manera en que lo habíamos observado en el capítulo anterior:

Artículo 25. Acción y omisión. La conducta punible puede ser realizada por acción o por omisión.

115 Corte Suprema de Justicia, Sala de Casación Penal, sentencias de casación del 7 de marzo de 2007, rad. n. ${ }^{\circ} 23825$ (caso de la Masacre de Machuca), Corte Suprema de Justicia SP1432-2014, rad. n. ${ }^{\circ}$ 40214, Corte Suprema de Justicia, Sala de Casación Penal, 12 de febrero de 2014, del 8 de agosto de 2007, rad. n. 25974 (caso Yamid Amat) y Corte Suprema de Justicia, Sala de Casación Penal, 12 de septiembre de 2007, rad. n. 24448 (Masacre de La Gabarra). 
Quien tuviere el deber jurídico de impedir un resultado perteneciente a una descripción típica y no lo llevare a cabo, estando en posibilidad de hacerlo, quedará sujeto a la pena contemplada en la respectiva norma penal. A tal efecto, se requiere que el agente tenga a su cargo la protección en concreto del bien jurídico protegido, o que se le haya encomendado como garante la vigilancia de una determinada fuente de riesgo, conforme a la Constitución o a la ley.

Son constitutivas de posiciones de garantía las siguientes situaciones:

\section{Cuando se asuma voluntariamente la protección real de una persona o de una fuente de riesgo, dentro del propio ámbito de dominio. [...]}

Parágrafo. Los numerales 1, 2, 3 y 4 sólo se tendrán en cuenta en relación con las conductas punibles delictuales que atenten contra la vida e integridad personal, la libertad individual, y la libertad y formación sexuales.

Este artículo evoca la teoría de la intervención cuando el aporte es la infracción al deber de evitar un resultado por parte de quien asume voluntariamente la administración o custodia de una fuente de riesgo o el rol de jefe de un grupo de crimen organizado, esto por cuanto se advierte que quien haya asumido de manera voluntaria la protección de una fuente de riesgo, como lo es la administración de un grupo de crimen organizado, y no evite el resultado lesivo tendrá la misma responsabilidad penal por no haber evitado el delito que quien cometió la conducta delictiva, como si el aporte de quien omite evitar el resultado debiendo evitarlo se acumulara al aporte de la ejecución del delito de parte de otra persona y se juntaran en una conducta global atribuible al ejecutor y al administrador de la fuente de riesgo.

El artículo 25 del CP es útil para imputar responsabilidad a miembros los jefes de una organización criminal, independientemente de que participen en la ejecución de las fechorías o no. Por ejemplo, una organización trafica con migrantes ayudándolos a pasar la frontera a cambio de una cuantiosa remuneración, todo con el conocimiento y aprobación del jefe de la organización. En este caso, si se produce el tráfico de migrantes por orden o sin orden del jefe de la banda criminal, por el hecho de que el jefe, que puede administrar su personal delincuencial y los bienes destinados a la organización criminal, decida no evitar el tráfico de inmigrantes, se le debería atribuir la misma responsabilidad que a los esbirros de la organización que ejecutaron el delito.

En este artículo del CP se encuentra lo relativo a la responsabilidad de quien asume voluntariamente la administración de una fuente de riesgo; sin embargo, solo se le imputa la conducta global en "las conductas punibles delictuales que atenten contra la vida e integridad personal, la libertad individual, y la libertad y formación sexuales", por ello consideramos se puede utilizar parcialmente para la propuesta de este escrito. 


\section{CONCLUSIONES}

- Las funciones de la pena determinan los modelos de imputación de responsabilidad penal. Para la función de la prevención general por intimidación los comportamientos voluntarios son el objeto de atención del derecho penal y para la función de la prevención general positiva el objeto de atención son las infracciones de deberes.

- La función de la retribución justa es un referente obligado para determinar la magnitud de la pena que se debe imponer por la comisión de un delito.

- El principio de legalidad dispone que los parámetros para determinar la magnitud de la pena, como la modalidad de la intervención, deben estar establecidos en la ley como una garantía de objetividad y justicia.

- Los grupos de crimen organizado son una organización con identidad propia; estructurada en forma jerárquica; con distribución de roles, funciones y competencias; que comete delitos graves por medio de conductas coordinadas que siguen un plan criminal; y que persigue el lucro en su actuar criminal.

- El derecho penal internacional conoce delitos similares a los que cometen los grupos de crimen organizado, por ello algunas instituciones de esta disciplina, como la metodología de la doble imputación, el concepto de plan criminal común y el concepto de máximos responsables, son útiles para regular formas de imputación de conductas en la delincuencia organizada.

- El modelo de imputación propio de la teoría del dominio del hecho no es el más adecuado para imputar conductas realizadas por un grupo de crimen organizado; en cambio, el modelo de imputación de la teoría de la intervención es bastante provechoso para este fin, solo que tiene los inconvenientes de no graduar la gravedad de los aportes y la pena que merecen y permite imputar conductas a personas a las que no se les debería imputar las conductas.

- Nuestro ordenamiento penal puede dar cabida parcialmente a la teoría de la intervención para atribuirles responsabilidad penal a los miembros de un grupo de crimen organizado, y con aportes del DPI se pueden corregir los desafueros de esta teoría.

\section{REFERENCIAS}

Ambos, Kai. ¿Cómo imputar a los superiores crímenes de los subordinados en el derecho penal internacional?, Bogotá, Universidad Externado de Colombia, 2008.

Araque, Diego y Esteban Vásquez. "Reflexiones sobre la delimitación entre autor y partícipe: pasado, presente y futuro", en Nuevo Foro Penal, n. ${ }^{\circ}$ 91, Medellín, 2018. 
Balmaceda Hoyos, Gustavo. Estudios de derecho penal parte general, Bogotá, Ediciones Nueva Jurídica y Universidad de La Sabana, 2015.

Barrios, Miguel Ángel. Seguridad ciudadana, de lo municipal a lo continental, Buenos Aires, Editorial Biblos, 2013.

Buitrago, Ángela. "Delitos de grupos delictivos organizados y grupos armados organizados", en Lecciones de derecho penal, parte especial, 3. a ed., Bogotá, 2019.

Cassese, Antonio. Los límites de la responsabilidad penal individual bajo la doctrina de la empresa criminal común, Bogotá, Universidad Externado de Colombia, 2016.

Castañeda, Augusto. La represión penal del crimen organizado: estrategias metodológicas para judicializar graves violaciones a los derechos humanos, Bogotá, Nueva Jurídica, 2018.

Cordini, Nicolás Santiago. “El 'crimen organizado’: un concepto extraño al derecho penal argentino", en Revista Direito GV, vol. 2, n. . 1, Sao Paulo, 2017.

Diccionario de la Real Academia Española. [https://dle.rae.es/?w=determinar].

El Tiempo. “'Clan del Golfo’ buscó a Farc y ELn para evitar extradición”, Bogotá, 22 de abril de 2019, disponible en [www.eltiempo.com/justicia/conflicto-y-narcotrafico/ maniobras-con-las-que-clan-del-golfo-han-buscado-evitar-extradicion-351912].

García Amado, Juan Antonio. La filosofía del derecho de Habermas y Luhmann, Bogotá, Universidad Externado de Colombia, 1997.

Gómez Pavajeau, Carlos Arturo. Aspectos liberales y sociales del derecho penal, Bogotá, Ediciones Nueva Jurídica, 2013.

Gómez Pavajeau, Carlos Arturo. Estudios de dogmática en el nuevo código penal, parte I, 3. a ed., Bogotá, Giro Editores, 2009.

Gómez Pavajeau, Carlos Arturo. Estudios de dogmática en el nuevo código penal, parte II, 3. ${ }^{a}$ ed., Bogotá, Giro Editores, 2009.

Gómez Pavajeau, Carlos. Introducción al derecho penal constitucional, Bogotá, Ediciones Nueva Jurídica, 2012.

González Amado, Iván. "El concepto de máximos responsables”, en Memorias de la XXXVIII jornadas internacionales de derecho penal: justicia negociada, justicia transnacional y crimen organizado, Bogotá, Universidad Externado de Colombia, 2017. 
González Amado, Iván. "La punibilidad", en Lecciones de derecho penal, parte general, Bogotá, Universidad Externado de Colombia, 2002.

Gutiérrez Sanín, Francisco. "Conexiones coactivas: paramilitares y alcaldes en Colombia”, en Revista Análisis Político, vol. 28, n. ${ }^{\circ}$ 85, Universidad Nacional, 2015.

Hegel, Georg Wilhelm Friedrich. Filosofía del derecho, Angélica Mendoza (trad.),

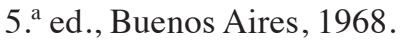

Hernández Esquivel, Alberto; José Manuel Díaz Soto y Carlos A. Gómez Pavajeau. "Autoría y participación", en Lecciones de derecho penal, parte general, 3. a ed., Bogotá, Universidad Externado de Colombia, 2019.

Hörnle, Tatjana. Teorías de la pena, traducción de Nuria Pastor, Bogotá, Universidad Externado de Colombia, 2015.

Jakobs, Günther. Injerencia y dominio del hecho, traducción de Manuel Cancio Meliá, Bogotá, Universidad Externado de Colombia, 2001.

Jakobs, Günther. "La pena estatal: significado y finalidad", Derecho penal y sociedad, Eduardo Montealegre (coord.), Bogotá, Universidad Externado de Colombia, 2007.

Jakobs, Günther. "La intervención delictiva", en Derecho penal y sociedad, tomo II, Eduardo Montealegre (coord.), Bogotá, Universidad Externado de Colombia, 2007.

Jakobs, Günther. Sobre la teoría de la pena, traducción de Manuel Cancio Meliá, Bogotá, Universidad Externado de Colombia, 1998.

Kant, Immanuel. La metafísica de las costumbres, traducción y notas de Adela Cortina y Jesús Conill, 4. ${ }^{\text {a }}$ ed., Madrid, Tecnos, 2004.

Lampe, Ernst Joachim. La dogmática jurídico-penal entre la ontología social y el funcionalismo, traducción de Carlos Gómez, Guillermo Orce y Miguel Polaino, Lima, Grijley, 2003.

Lesch, Heiko. Intervención delictiva e imputación objetiva, traducción de Javier Sánchez-Vera, Bogotá, Universidad Externado de Colombia, 1997.

Lesch, Heiko. La función de la pena, traducción de Javier Sánchez-Vera, Bogotá, Universidad Externado de Colombia, 2000.

Llanos, Teddy Enrique. De las estructuras jerárquicas de poder en el derecho penal colombiano, Bogotá, Ediciones Doctrina y Ley, 2015. 
Londoño Mesa, Federico. "Concurso de personas en la conducta punible”, Derecho penal, parte general - fundamentos, Diego Araque (coord.), Medellín, Universidad de Medellín, 2009.

López, Claudia. Código Penal alemán, Bogotá, Universidad Externado de Colombia, 2002.

López Muñoz, Julián. Criminalidad organizada. Aspectos jurídicos y criminológicos, Madrid, Dykinson, 2015.

López Muñoz, Julián. Criminalidad organizada y terrorismo, Madrid, Dykinson, 2019.

Malamud, Samuel. "El concepto de crimen organizado: ciertos elementos para una mayor concreción", Revista Chilena de Derecho y Ciencias Políticas, vol. 7, n. . 1, Santiago, 2016.

Marxen, Klaus. "Intervención en un injusto sistemático grave. Consideraciones sobre una teoría jurídico-penal internacional del delito", en Autores, partícipes y superiores en la justicia internacional, Yesid Reyes Alvarado (coord.), Bogotá, Universidad Externado de Colombia, 2018.

Mir Puig, Santiago. Introducción a las bases del derecho penal, 2. ${ }^{a}$ ed., Buenos Aires, B de F, 2003.

Montealegre, Eduardo. Conferencia del IX conversatorio de la jurisdicción constitucional. Diálogo constitucional para la paz, Medellín, 2013, disponible en [https:// www.youtube.com/watch?v=Y5QnSuVS800\&list=WL\&index $=12 \& \mathrm{t}=0 \mathrm{~s}]$.

Montealegre, Eduardo y Jorge Perdomo. Funcionalismo y normativismo penal, Bogotá, Universidad Externado de Colombia, 2006.

Olasolo, Héctor. Introducción al derecho internacional penal, Bogotá, Universidad del Rosario, 2015.

Polaino-Orts, Miguel y Günther Jakobs. Criminalidad organizada, formas de combate mediante el derecho penal, México, Editorial Flores, 2013.

Quintero, María Eloísa. “Acción, comunicación e injusto penal”, en Derecho penal y sociedad, Eduardo Montealegre (coord.), Bogotá, Universidad Externado de Colombia, 2007.

Reyes Alvarado, Yesid. Autores, partícipes y superiores en la justicia internacional, Yesid Reyes Alvarado (coord.), Bogotá, Universidad Externado de Colombia, 2018. 
Reyes Alvarado, Yesid. "Intervención delictiva e imputación objetiva en Derecho penal contemporáneo”, en Revista Internacional, n. 21, Bogotá, Legis, 2007.

Roxin, Claus. Derecho Penal, Parte General, tomo II: Especiales formas de aparición del delito, traducción y notas de Diego Manuel Luzón Peña, José Manuel Paredes Castañón, Miguel Díaz y García Conlledo y Javier de Vicente Remesal, Madrid, Civitas, Thomson Reuters, 2014.

Roxin, Claus. "Dirección de la organización como autoría mediata”, Manuel Abanto (trad.), en Anuario de Derecho Penal y Ciencias Penales, t. 62, Madrid, Ministerio de Justicia de España, 2009.

Roxin, Claus. Problemas básicos del derecho penal, traducción de Diego Manuel Luzón Peña, Madrid, Editorial Reus, 1976.

Roxin, Claus. "Problemas de autoría y participación en la criminalidad organizada", en Revista Penal, n. ${ }^{\circ}$ 2, Huelva, Universidad de Huelva, 1998.

Ruiz López, Carmen Eloísa y Miguel Córdoba Angulo. Lecciones de derecho penal, parte general, 3. a ed., Bogotá, Universidad Externado de Colombia, 2019.

Sánchez, Carlos. "Sobre el concepto de crimen organizado. Significación de su contenido en la legislación penal salvadoreña", en Revista Policía y Seguridad Pública, n. ${ }^{\circ}$ 2, El Salvador, 2012.

Suárez Díaz, Elena y Ernesto Velasco Chaves. "Máximos responsables", en Justicia transicional: verdad y responsabilidad, Gerardo Barbosa, Carlos Bernal y Andrés Rolando Ciro Gómez (eds.), Bogotá, Universidad Externado de Colombia y Ejército Nacional de Colombia, 2016.

Urbano Martínez, José. "Concepto y función del derecho penal”, en Lecciones de derecho penal, parte general, Bogotá, Universidad Externado de Colombia, 2002.

Villar Borda, Luis. "El Estado de derecho y el Estado social de derecho", en Revista Derecho del Estado, n. ${ }^{\circ}$ 20, Bogotá, Universidad Externado de Colombia, 2007.

Vogel, Joachim. "Responsabilidad individual en el derecho penal internacional. A la vez una aportación a los modelos de regulación de la intervención”, en Autores, partícipes y superiores en la justicia internacional, Yesid Reyes Alvarado (coord.), Bogotá, Universidad Externado de Colombia, 2018.

Weigend, Thomas. "Consideraciones sobre la responsabilidad del superior en el derecho penal internacional", en Autores, partícipes y superiores en la justicia internacional, Yesid Reyes Alvarado (coord.), Universidad Externado de Colombia, 2018. 
Zaffaroni, Eugenio. El crimen organizado: una categoría frustrada, Bogotá, Leyer, 1996.

Zúñiga, Laura. "Criminalidad organizada, derecho penal y sociedad. Apuntes para el análisis", en Revista Foro Jurídico, n. . 10, Lima, Pontificia Universidad de Perú, 2010.

\section{Juriprudencia}

Corte Constitucional, sentencia C-328 de 2016.

Corte Constitucional, sentencia C-579 de 2013

Corte Constitucional, sentencia C-806 de 2002.

Corte Constitucional, sentencia C-939 de 2002.

Corte Constitucional, sentencia SU-747 de 1998.

Corte Constitucional, sentencia T-499 de 1992.

Corte Constitucional, sentencia T-701 de 2006.

Corte Suprema de Justicia, Sala de Casación Penal, proceso n. ${ }^{\circ}$ 27677, 2 de diciembre de 2008 .

Corte Suprema de Justicia, Sala de Casación Penal, radicación n. 32672, del 3 de diciembre de 2009.

Corte Suprema de Justicia, Sala de Casación Penal, radicación n. 33254, del 27 de febrero de 2013.

Corte Suprema de Justicia, Sala de Casación Penal, radicación n. ${ }^{\circ}$ 41758, del 18 de mayo de 2016.

Corte Suprema de Justicia, Sala de Casación Penal, sentencia del 12 de septiembre de 2007 , radicación n. ${ }^{\circ} 24448$.

Corte Suprema de Justicia, Sala de Casación Penal, sentencia del 21 de agosto de 2003, radicación n. ${ }^{\circ} 19213$.

Corte Suprema de Justicia, Sala de Casación Penal, sentencia del 23 de febrero de 2010 , radicación n. ${ }^{\circ} 32805$. 
Corte Suprema de Justicia, Sala de Casación Penal, sentencia del 5 de octubre de 2006 , radicación n. ${ }^{\circ} 22358$.

Corte Suprema de Justicia, Sala de Casación Penal, sentencia del 7 de marzo de 2007 , radicación n. ${ }^{\circ} 23825$.

Corte Suprema de Justicia, Sala de Casación Penal, sentencia del 8 de agosto de 2007 radicación n. ${ }^{\circ} 25974$.

Corte Suprema de Justicia, Sala de Casación Penal, sentencia del 14 de septiembre de 2011 , radicación $n$. $^{\circ} 32000$.

Corte Suprema de Justicia, Sala de Casación Penal SP1432-2014, del 12 de febrero de 2014, radicación n. ${ }^{\circ} 40214$.

\section{Otros}

Constitución Política de Colombia.

Convención de Naciones Unidas contra la delincuencia organizada transnacional.

Fiscalía General de la Nación, Directiva 1 de 2012.

Fiscalía General de la Nación, Directiva 2 de 2015.

Ley 1908 de 2018.

Ley 599 de 2000 .

Ley Orgánica 10/1995 de España. 